\title{
Tackling Poverty in Old Age: A Universal Pension for Sri Lanka
}
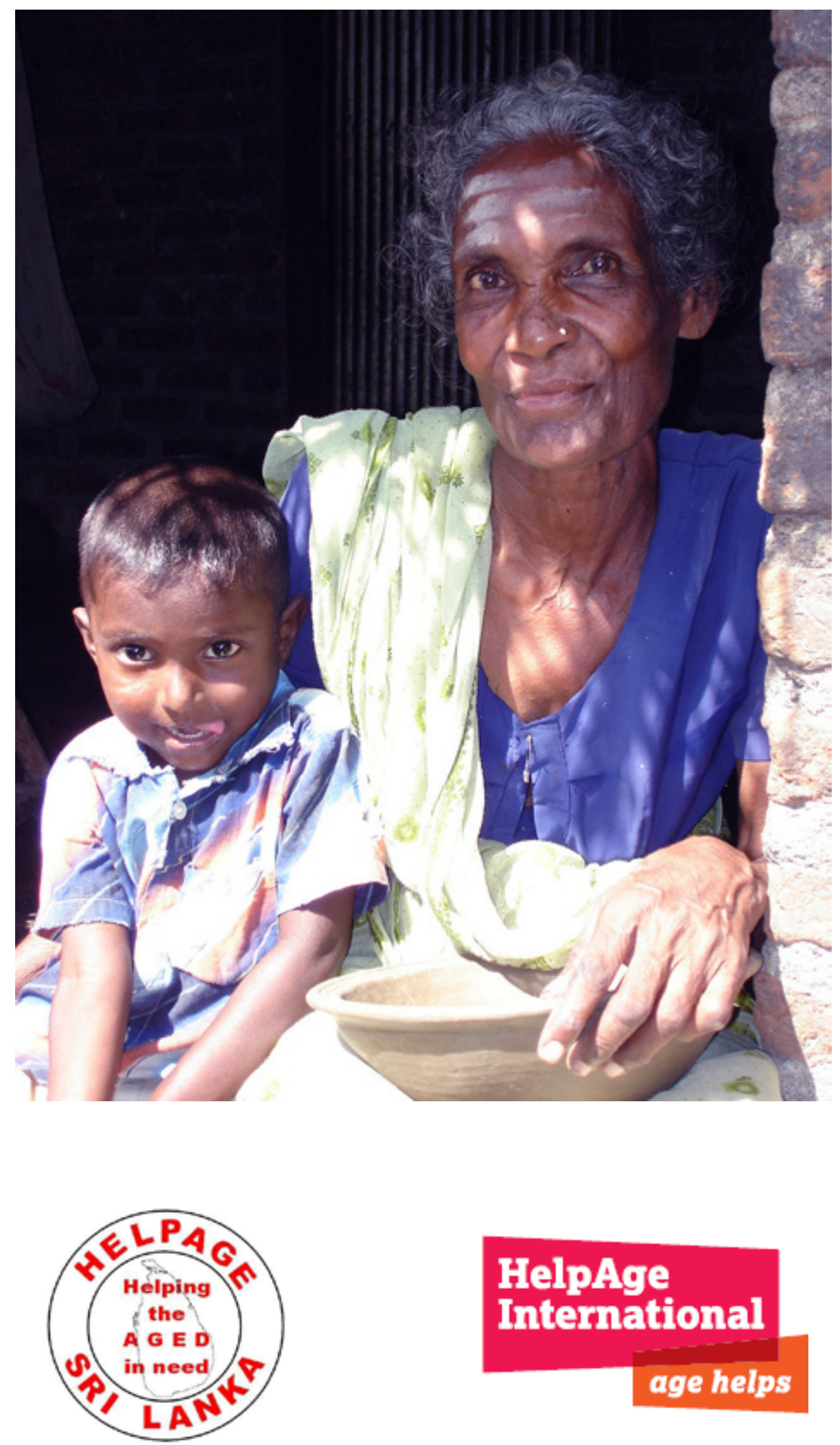

HelpAge

International 


\section{Acknowledgements}

This report was prepared for HelpAge International on behalf of HelpAge Sri Lanka by Dr. Larry Willmore of the International Institute for Applied Systems Analysis (IIASA) in Laxenburg, Austria and Stephen Kidd, Director of Policy and Communications at HelpAge International, London UK. They were supported by a small team that included Astrid Walker and Jonathan Barden of HelpAge International.

The report also draws on work commissioned from a team at the Institute of Policy Studies led by Dr. Nisha Arunatilake, and two consultants, Professor Siddhisena and Dr. Wanigaratne, supplied with the guidance of Mrs $\vee$ Jegarasasingham, Additional Secretary of the Ministry of Social Services and Social Welfare.

In preparing the report, HelpAge International would like to acknowledge the excellent support received from HelpAge Sri Lanka, in particular its Chairman, Deshabandu Tilak de Zoysa and its Chief Executive, Samantha Liyanawaduge.

HelpAge International and HelpAge Sri Lanka are grateful to Help the Aged for funding the study and this report.

\section{HELPTHEAGED WE WILL}

Help the Aged provides core funding to HelpAge and is also a leading member of HelpAge's global network.

Published by HelpAge International

PO Box 32832

London N1 9ZN, UK

Email: info@helpage.org

Web: www.helpage.org

Copyright $(\subset)$ HelpAge International 2008

Registered charity no. 288180

Any parts of this publication may be reproduced without permission for educational and non-profit purposes if the source is acknowledged.

Front cover photo: Vidarshi de Silva Wijeyeratne/HelpAge Sri Lanka 


\section{Contents}

$\begin{array}{ll}\text { Executive summary } & 1\end{array}$

1. Introduction 3

2. Pensions in Sri Lanka 5

2.1 Existing pension schemes 6

2.1.1 The Public Service Pension Scheme (PSPS) 6

2.1.2 The Employees' Provident Fund (EPF) 6

2.1.3 Informal sector contributory pension schemes 6

2.1.4 Samurdhi and Public Welfare Assistance Allowance (PAMA) 7

2.1.5 Indexed retirement pensions 7

2.2 Challenges with the existing pension schemes 8

2.2.1 Low coverage 8

2.2.2 Low benefits 8

3. A universal pension: a new paradigm for pension provision in 10

Sri Lanka

3.1 A universal pension for Sri Lanka 10

3.2 A universal pension versus a targeted pension 11

3.3 Reform of contributory pensions in Sri Lanka 15

4. Impacts of non-contributory pensions - international experience 17

5. The fiscal cost of a universal pension 20

$\begin{array}{lll}5.1 & \text { Age of eligibility } & 20\end{array}$

$\begin{array}{lll}5.2 & \text { Size of grant } & 20\end{array}$

$\begin{array}{ll}5.3 \text { Administrative costs } & 21\end{array}$

5.4 Funeral benefit 22

5.5 Fiscal costs of the universal pension in 2007

5.6 Initial set-up costs 23

5.7 Comparison of Sri Lanka costs with international experience 24

5.8 Fiscal cost of the Sri Lanka universal pension over time 25

\begin{tabular}{ll} 
6. & Financing a universal pension \\
\hline
\end{tabular}

7. Key design and implementation issues 29

$\begin{array}{lll}7.1 & \text { Registration processes } & 29\end{array}$

7.1.1 Establishing eligibility 29

$\begin{array}{ll}\text { 7.1.2 Process of registration } & 29\end{array}$

$\begin{array}{ll}\text { 7.1.3 De-registration of beneficiaries } & 30\end{array}$

7.1.4 Creation of a registry for pension recipients 30

$\begin{array}{ll}\text { 7.1.5 Payment mechanisms } & 31\end{array}$

8. Conclusion 33

$\begin{array}{ll}\text { References } & 34\end{array}$

Annex A: International experience with universal pensions 37

Annex B: The possibility of rule-based targeting in Sri Lanka 39

Annex C: Pension-testing a non-contributory pension 40

Annex D: Calculations of fiscal cost 42 


\section{List of figures}

Figure $1 \quad$ Population ageing in Sri Lanka, 2001-2041 3

Figure $2 \quad$ Sri Lanka's working age population and labour force 5

Figure 3 Proportion of means-tested pensions in India accruing to each quintile 12

Figure 4 Proportion of means-tested pensions in Chile accruing to each quintile 12

Figure $5 \quad$ Impact of the non-contributory pension on poverty in South Africa 17

Figure $6 \quad$ Sri Lanka's National Poverty Line, 2003-2008 21

Figure $7 \quad$ Transfers via universal pensions as percentage of GDP international experience $\quad 24$

Figure $8 \quad$ Mauritius and Sri Lanka compared, 1950-2007 25

Figure $9 \quad$ Fiscal cost of a universal pension with trend growth, 2007-2041 26

Figure $10 \quad$ Fiscal cost of a universal pension with slow growth, 2007-2041 26

\section{List of tables}

$\begin{array}{lll}\text { Table } 1 & \text { Universal age pensions around the world } & 11\end{array}$

$\begin{array}{lll}\text { Table } 2 & \text { Fiscal cost of a universal pension, Sri Lanka } 2007 & 23\end{array}$

Table $3 \quad$ Financing the universal pension with a surcharge on

consumption taxes $\quad 27$ 


\section{Executive summary}

Sri Lanka's population is ageing rapidly. Residents over 60 years of age comprise $9 \%$ of the population and will reach $25 \%$ by 2041 . The existing pension system in Sri Lanka is unable to guarantee a minimum income for older people to prevent them from living in poverty. Coverage of pensions is small - probably no more than $10 \%$ to $15 \%$ of the population have access to any form of pension scheme - and, most pension schemes provide benefits that are well below the poverty line. Even if existing pension schemes were to be improved, they would still be unable to provide income security for the vast proportion of the older population.

If Sri Lanka is to be successful in tackling old age poverty, there needs to be a fundamental shift in pension policy. Internationally, there is clear evidence that, in countries with high levels of poverty and informal employment, the simplest and most effective form of pension is a universal non-contributory pension paid out of government revenues. In such pension schemes, every older person - upon reaching a specific age - receives the same minimum benefit to keep them out of poverty.

A number of countries - both developed and developing - have put in place universal pension schemes. The first country to do so was New Zealand in 1940 but, since then, a range of countries as diverse as Mauritius, Nepal, Namibia, Bolivia and Kosovo have established similar schemes. Evidence indicates that these pension schemes have been very successful in tackling old age poverty. They are very simple to administer and are politically popular.

Universal pensions can play an important role as the foundation pillar of a broader pension system, upon which other pension pillars can be built, whether they be mandatory or voluntary contributory schemes. Universal pensions have significant advantages over means-tested pension schemes which are much less effective in reaching the poor and create a series of perverse incentives, including discouraging people from working in old age. Means-tested pensions can also undermine contributory pension schemes by discouraging people from saving for old age. Universal pensions create no perverse incentives and provide a solid basis upon which to establish a system of contributory pensions.

This study provides estimates of the fiscal cost of a universal pension in Sri Lanka. It challenges those opponents of universal pensions who claim that such schemes are unaffordable, despite the fact that many developing countries have already successfully put in place such schemes. The study demonstrates that a universal pension in Sri Lanka can be affordable.

The study proposes a level of cash benefit for a universal pension in Sri Lanka at the national poverty line, currently around 2,950 rupees (US\$27) per month. This would provide older people with a benefit that is approximately three times as large as those offered by the most generous informal sector contributory schemes. The study estimates the cost of a pension for four qualifying ages: $60,65,70$ and 75 years. Calculations also include the costs of administering the schemes and providing a funeral benefit equivalent to three months of pension benefits.

Estimates indicate that the cost of providing a pension to everyone in Sri Lanka above the age of 70 would be $\mathbf{0 . 8 \%}$ of GDP. When compared to the cost of universal pensions in other developing countries - estimated as a proportion of GDP - such a scheme would be one of the least expensive schemes internationally. The study also 
indicates that a pension for everyone over 60 would cost $1.8 \%$ of GDP, for those over 65 it would be $1.2 \%$ of GDP and for over $75 \mathrm{~s}$ it would be $0.4 \%$ of GDP.

Costs of a universal pension up to 2041, adjusted for inflation, are also provided, to take into account the growing number of older people. Assuming a continuation of the trend per capita growth rate over the past 20 years of $3.6 \%$ per year, the study indicates that a universal pension for those over-70s would become increasingly affordable, dropping to $0.6 \%$ of GDP by 2041 . If however, growth of per capita GDP were to fall to $1.8 \%$ per year, the fiscal burden of a universal pension would increase, but only modestly, rising to $1.1 \%$ of GDP for everyone over 70 .

The financing of a universal pension is, ultimately, a question of political will. But, even with political commitment behind a pension, governments still need to find the necessary funds. Taxpayers may be more willing to finance age pensions if the additional taxes required are collected exclusively for the purpose of universal pensions and they are assured that the pension benefits will be protected. Since everyone benefits from universal pensions, it is important that everyone contribute to their finance. The tax, therefore, ought to have a broad base.

Consumption taxes are one option in Sri Lanka. The study indicates that a small increase in VAT and excise duties could provide sufficient funding to finance a universal pension. For example, an increase in VAT of $5 \%$ to $5.5 \%$ (along with similar small increases at higher levels of VAT) would pay for a pension for everyone over 70 years. For lower ages of eligibility the surcharge would, of course, be higher.

A universal pension would be relatively simple to set up and administer in Sri Lanka. Registration of beneficiaries would be unproblematic because the only information required from applicants is proof of age and residence. Most will already have a national identity card and, for those lacking a card, the more than 10,000 village elders' societies across the country can help in verifying their age. One of the main challenges in any pension system is ensuring that beneficiaries are de-registered on their death. A simple way of encouraging the reporting of deaths is to provide a funeral benefit equivalent to, perhaps, three months of pension benefits if a pensioner's death is reported within 20 days.

A universal pension set at the poverty line is likely to transform the lives of older people and their families across Sri Lanka. It will almost certainly be politically very popular with citizens and could play an important role in building social cohesion and strengthening the social contract between the state and people from all ethnic backgrounds. 


\section{Introduction}

Sri Lanka's population is ageing rapidly. This ageing is driven largely by a decline in fertility which, in 1994, fell below the replacement rate of 2.1 births per woman. The last population census, in 2001 , counted 18.7 million residents. Assuming a constant total fertility rate of 1.98 , the population is projected to increase to 21.9 million in 2036 before starting a long period of contraction (De Silva, 2007).

Residents older than 60 years of age numbered 1.7 million in 2001 and are expected to reach 5.4 million by 2041 . As a proportion of total population, the increase is from $9 \%$ to $25 \%$. The 'oldest old' - those older than 75 years - are projected to increase from 400 thousand in 2001 to 1.7 million in 2041 (see Figure 1). As their numbers rise, older people will increasingly become a more powerful group and government will have to respond to their demands, including the demand for a basic pension.

Figure 1. Population ageing in Sri Lanka, 2001-2041 ${ }^{1}$

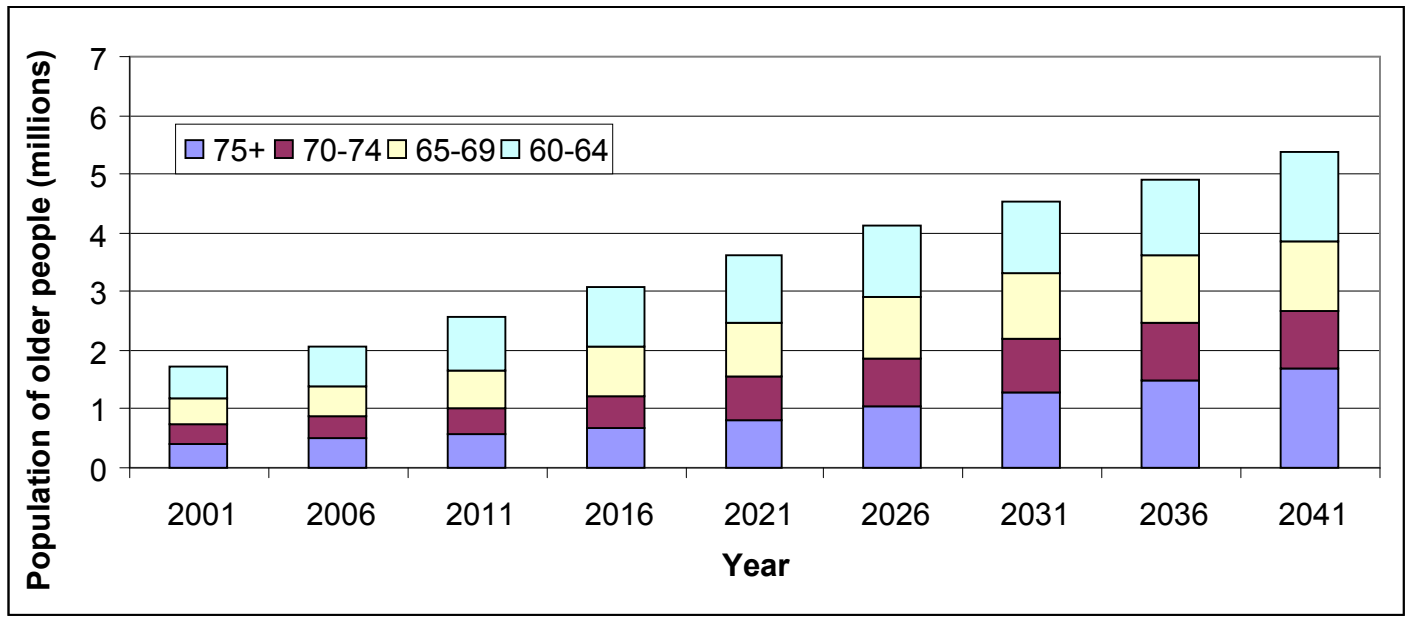

Yet, Sri Lankans - with few exceptions - still have no access to pensions in old age. Although older people traditionally turn to their families for support when they can no longer work and their savings are exhausted, population ageing places increasing demands on this system, which is already showing signs of strain (World Bank, 2008, chapter 2).

Pension systems exist to satisfy two main goals: (1) to tackle poverty in old age by providing a minimum income; and (2) to smooth consumption over the life-cycle. This study focuses mainly on the first function, which can be performed only by government. No other institution, including the family, can guarantee that no older person lives in poverty. The second function can be handled with occupational pensions and through contributions to diverse types of public and private retirement income schemes. Of course, pensions should also be designed to impact on other potential policy objectives, such as promoting equity and social cohesion - both of which will, ultimately, also contribute to reducing poverty and promoting economic growth.

\footnotetext{
${ }^{1}$ Source: De Silva (2007)
} 
Governments who want to ensure that no older person lives in poverty have two choices. They can provide basic age pensions as a universal benefit or they can provide them as a targeted benefit. Universal benefits are given to everyone regardless of employment status, assets, personal income, the income of relatives, or the income of other members of the household. Targeted benefits are given only to those deemed 'needy' or 'deserving'. In Sri Lanka, health care and basic education are universal benefits. The Samurdhi poverty relief programme is an example of a targeted benefit.

The report will propose that a universal non-contributory pension is the most appropriate and effective mechanism for Sri Lanka if the country desires to tackle poverty in old age. Targeted benefits tend to be characterised by high administrative costs, complex eligibility criteria and application procedures, exclusion of many poor people, leakage of benefits to the non-poor and, very often, corruption (Mkandawire 2005; Dutrey 2007). The generally low take-up of benefits is a result of complex application procedures, lack of information and the stigma of means-tests (Kleven and Kopczuk, 2008). In contrast, universal benefits are simple and transparent. Administrative complexity is not necessary for a universal programme because everyone is eligible. All that is required to receive a universal age pension is evidence of age and legal residence. Applicants are not penalised if they have other pension income or savings and are not obliged to retire from paid employment.

The report will begin by examining the existing pension system in Sri Lanka and conclude that, in its current structure, it is - and will continue to be - unable to achieve the objective of providing older people with a minimum income. The report will then propose a revised pension model for Sri Lanka based, essentially, on putting in place a non-contributory pension for all older people which will act as a foundation pillar of the entire future pension system. International experience with similar pension models will be explored and it will be shown that universal pensions are, without doubt, the most successful pensions in tackling poverty in old age. The fiscal cost of a universal pension will then be estimated, followed by a discussion of potential means by which this pension could be funded. Finally, a number of key design issues will be explored. 


\section{Pensions in Sri Lanka: the current situation}

There are two major challenges facing the existing pension system in Sri Lanka: 1) coverage is low, with around $85 \%$ to $90 \%$ of older people unable to access a regular pension; and, 2) even for those who can access a pension, many find that the actual level of the benefit they receive is well below the poverty line.

Any reform and expansion of Sri Lanka's retirement income system will be tremendously challenging, unless a paradigmatic shift in pensions policy-thinking is embraced. The stylised facts of Sri Lanka's labour market are shown in Figure 2. Roughly 13 million individuals - two-thirds of the population - make up Sri Lanka's "working age population" aged 18 to 65 years. Of these, approximately 3 million work in formal labour markets (public and private), 4.7 million are employed in the informal sector and 2.1 million work without pay as housewives. The remaining 3.3 million presumably are either students or retirees, so are not expected to contribute to a retirement scheme at this point in their lives. The biggest challenge is pension coverage for workers in the informal sector.

Figure 2. Sri Lanka's working age population and labour force ${ }^{2}$

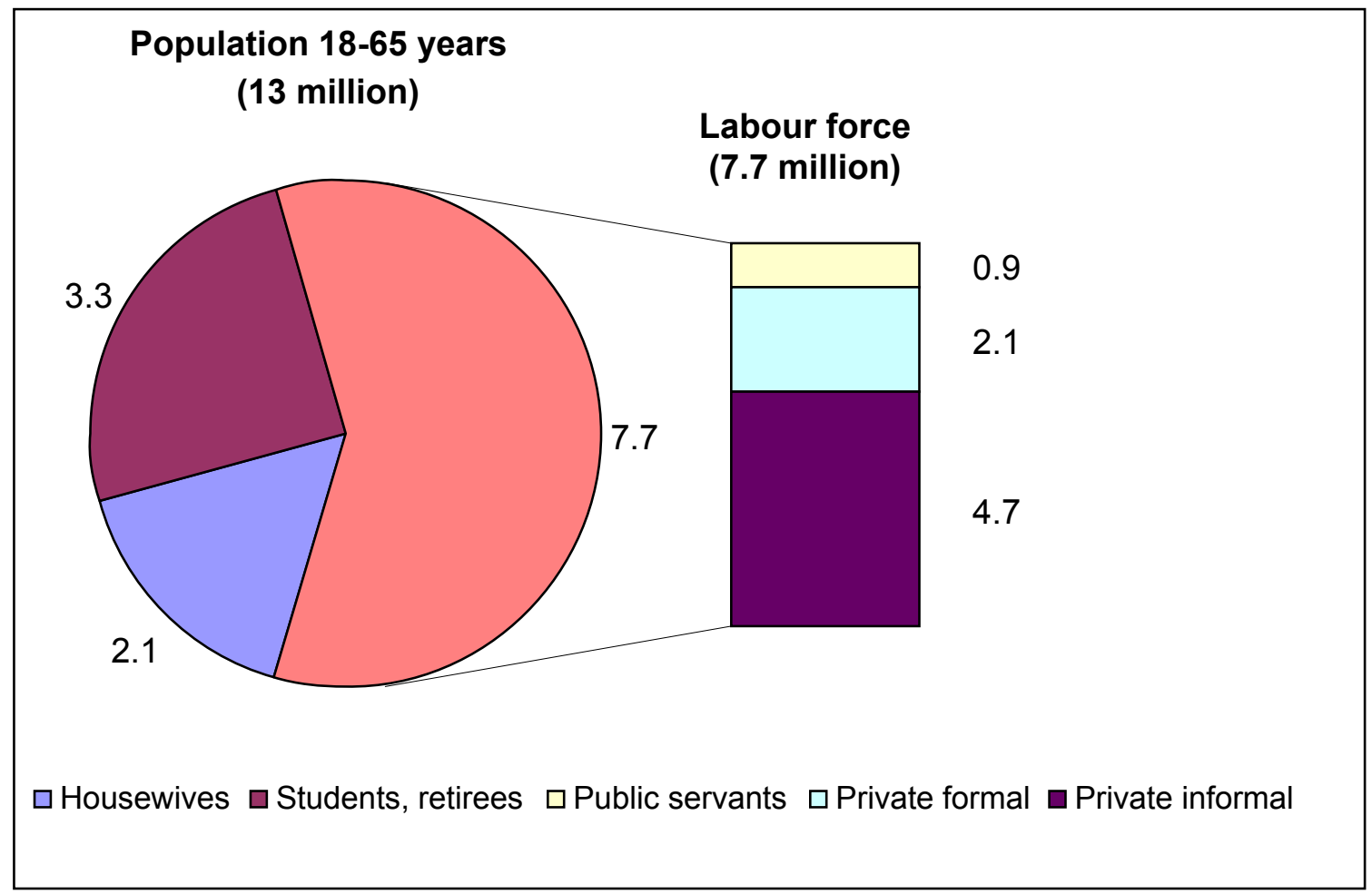

Housewives, who have little or no wage earnings, are often neglected in the discussion of pension design. But, housewives also require access to a minimum income if they are to survive in old age with dignity. If it is not provided by government or by the charity of family and friends, it will have to be provided by the savings and pension contributions of the husband. Most, if not all, housewives are likely to be dependants of workers in the formal sector. Wives of workers in the

\footnotetext{
${ }^{2}$ Source: Rannan-Eliya (2006)
} 
informal sector are more apt to work for wages or - in the case of farm wives - to contribute to household production of cash crops.

\subsection{Existing pension schemes}

The pension system in Sri Lanka is built, essentially, around a number of noncontributory and contributory schemes covering both those working in the formal sector and a small proportion of the informal sector labour force. The main pension and pseudo-pension schemes are described below.

\subsubsection{The Public Service Pension Scheme (PSPS)}

The PSPS is a non-contributory benefit financed from general government revenues, currently at a fiscal cost of $2 \%$ of GDP. It is provided to former civil servants. A full pension is payable from age 55 (men) or age 50 (women) and must be taken at latest by age 60 . The pension is based on final salary (85-90\% replacement after 30 years of service), is not taxable, but is not indexed for inflation. There is no explicit spousal allowance, but widows (widowers) receive a survivor's pension following the death of their husband (wife). There is a separate, contributory Widows, Widowers and Orphans Pension Scheme that provides benefits to survivors of public sector workers who die in service.

\subsubsection{The Employees' Provident Fund (EPF)}

The EPF is much larger than the PSPS but it provides only lump sum payments, not a retirement pension. Government requires contributions equal to $20 \%$ of wages ( $8 \%$ from workers and $12 \%$ from employers), which are credited to a notional account of the worker and invested almost solely in government securities and loans. The accumulated funds can be withdrawn on retirement, which can be as early as age 55 for men and age 50 for women. The scheme covers most workers in the formal sector who do not participate in the PSPS. At the end of 2006, the EPF had 11.3 million member accounts, of which 2.0 million were active (Central Bank of Sri Lanka, 2006). There are also several small Approved Private Provident Funds (APPFs) and Private Contributory Pension Schemes created by enterprises that opted out of the EPF.

\subsubsection{Informal sector contributory pension schemes}

The 4.7 million workers in Sri Lanka's informal sector are potentially covered by a large number of contributory pension schemes, but they do not perform particularly well. All the schemes are voluntary, and neither benefits nor contributions are indexed.

The oldest and largest scheme is the Farmers' Pension Scheme, begun in 1987 and administered by the Agricultural and Agrarian Insurance Board (AAIB). The scheme has over 680,000 accounts but, due to poor record-keeping, it is not known how many are active. Eriyagama \& Rannan-Eliya (2003, p. 18) report that: "it is believed that at least half the enrolees have defaulted and are no longer active contributors". Contributions are collected in half-yearly instalments and the size of the pension at age 60 depends on the age when membership begins. The required contributions are small, ranging from 84 instalments of 130 rupees for someone joining at age 18 to ten instalments of 690 rupees for someone joining at age 55. 
The other voluntary schemes for workers in the informal sector are much smaller. The Fishermen's Pension Scheme, which began in 1990 and is also administered by the AAIB, has about 48,000 accounts. The Self-Employed Persons Pension Scheme dates from 1996, has 70,000 accounts and is administered by the Social Security Board (SSB). In 2006 the SSB launched five new schemes for the self-employed, for a total of six: "Sahana" (the original scheme), "Thilina", "Isuru", "Sarana", "Surakuma", and "Dhanalakshmi". In addition to these schemes, the SSB has introduced various programmes that target different types of workers:

- Migrant Workers ("Sesatha" - introduced in 2007)

- Indigenous medical doctors (2005)

- Small and Medium Entrepreneurs (“Kam Diriya” - 2006)

- Artists ("Saraswathi" 2008)

- Senior Citizens (2007)

- Journalists ("Prathishta"- 2007)

- Small-scale tea producers ("Randalu")

- Hand Loom Manufacturers- ("Ransalu"- 2004)

- Beauticians (“Rusiru”)

No information is available on enrolment in these programmes but affiliates, for the moment, are believed to be small.

At present, the schemes can afford to pay benefits to pensioners because the ratio of pensioners to contributors is small. However, as this balance shifts and the number of pensioners increase, it is likely that the schemes will find that they have insufficient funds to pay pensions. Government may then be asked to step in to cover the gap.

\subsubsection{Samurdhi and Public Welfare Assistance Allowance (PAMA)}

Although not strictly a pension scheme, one of the functions of the Samurdhi scheme, which dates from 1995, is to provide income support to the poorest older people. The scheme is a social cash transfer financed by government revenue which aims to reach households with monthly incomes less than 1,500 rupees (US\$14) a month. Many of these households contain older people. However, despite the low income requirement for eligibility, the scheme is very poorly targeted. The World Bank (2008) reports that: "More than 40 percent of the bottom consumption quintile is excluded and $44 \%$ of spending is on the top three quintiles." PAMA is an older scheme dating from 1939 and also makes payments to households with a monthly income of less than 1,500 rupees (US\$14). There is no co-ordination between the two schemes, so some households receive both allowances while other households receive nothing.

\subsubsection{Indexed retirement pensions}

Indexed retirement pensions are rare in Sri Lanka (Gopalakrishnan, 2008). Retired Members of Parliament have pensions indexed to the allowances of current sitting Members of Parliament, and retired Central Bank employees have pensions indexed to current Central Bank salaries. Some commercial banks, including the Bank of Ceylon and People's Bank (for those who retired prior to 1996), provide retirement benefits that are indexed to prices. 


\subsection{Challenges with the existing pension schemes}

There are two main challenges facing the existing pension scheme: low coverage and inadequate levels of benefit.

\subsubsection{Low coverage}

There are a number of reasons why the vast majority of Sri Lanka's older population do not have access to a pension or any other form of income support in old age:

- The PSPS only benefits former civil servants who are a small proportion of the population.

- The EPF, although it has mandatory contributions, does not, in fact, provide any regular cash benefits to older people. It is, instead, in reality no more than a savings scheme. On retirement, members of the EPF cash in their "savings," receiving them as a lump sum. Even if they were placed in a bank account, rather than consumed immediately, the money is unlikely to last for very long into old age. Once the savings are gone, members are left with no other form of pension income.

- The informal sector contributory schemes have very poor coverage rates. It is difficult to obtain good data on the reach of these schemes but, as of 2007, approximately 56,000 retired farmers and fishermen and 4,000 self-employed were receiving pension. Because of poor record-keeping, we have no idea how many people are making regular contributions to these schemes and even less information on how many make enough contributions to qualify for a retirement pension.

- The ineffective targeting of the Samurdhi programme means that the vast majority of poor older people miss out. According to the World Bank (2008): "more than $70 \%$ of old people belonging to the bottom quintile are excluded from the programme."

\subsubsection{Low benefits}

Low benefit levels characterise all of Sri Lanka's pension - or pseudo-pension schemes and, in most cases, are insufficient to provide income security in old age:

- Although initial benefits provided by the PSPS are generous, they are not indexed and are adjusted only sporadically for increases in the cost of living. In the future, the real value of these benefits might fall dramatically.

- Benefits from the informal sector contributory schemes are small, in fact well below the poverty line. Those in the farmers' and fishermen's schemes receive monthly pensions of 1,000 rupees (US\$9.20) while self-employed retirees receive 500 rupees (US\$4.60). In part, this is the result of: 1 ) the contributions paid by members being too small to accumulate a large enough fund; and, 2) the non-indexing of contributions and benefits for price inflation. For instance, a person joining the Farmers' scheme at 18 can expect to receive a pension benefit of 4,167 rupees a month. However this figure is 
deceptive since benefits are in nominal rupees and are not indexed. For an 18 year old joining today, the purchasing power of the promised 4,167 rupee pension when it begins at age 60 will be only 76 rupees assuming $10 \%$ price inflation, and 12 rupees assuming 15\% inflation (Eriyagama \& Rannan-Eliya 2003:47).

- The Samurdhi scheme only pays benefits ranging from 250 rupees (US $\$ 2.30$ ) for a one-person household to 1,000 rupees (IS\$9.20) for households of six or more people. Compulsory savings are deducted, so the net transfer is less.

PAMA pays even less: 100 rupees (US $\$ 0.92)$ a month for a single person and a maximum of 330 rupees (US\$3.00) for a family with four or more persons. Benefits from both schemes are only a tiny portion of the national poverty line. 


\section{A universal pension: a new paradigm for pension provision in Sri Lanka}

It is clear that neither the contributory pensions nor means-tested benefits in Sri Lanka are able to provide a guarantee of a minimum income in old age. Clearly, the existing schemes need to be reformed and improved but, even if they were - and this would be a mammoth task - they would still be unable to provide income security for older people. Furthermore, it needs to be remembered that the main purpose of contributory pensions is to provide consumption smoothing for those with sufficient income to save for old age. They should not be regarded as a means of providing a minimum income in old age; in fact, no country in the world with a high proportion of its labour force in the informal sector has managed to provide good pension coverage through a contributory system.

Contributory pension schemes are important but they need to be viewed as a complement to other pension schemes which focus on providing a minimum income in old age. But, means-tested pensions are also not the answer; as discussed below, international experience demonstrates that such pension schemes have had little success in extending pension coverage to all older people living in poverty.

The only way in which Sri Lanka will ensure that the vast majority of older people receive a minimum income is by transforming entirely the paradigm surrounding policy-thinking on pension reform by moving away from a dependence on meanstesting and contributory benefits. Fortunately, international experience offers an answer.

\subsection{A universal pension for Sri Lanka}

There is clear evidence from a range of countries that the simplest and most effective form of pension for countries with high levels of poverty and informal employment is a universal non-contributory pension, paid out of government revenues. Every older person - upon reaching a specific age - would be able to receive a basic pension, one that is aimed at keeping them out of poverty. The level of the benefit should, therefore, be equivalent to the poverty line. The only qualifying condition for the pension would be citizenship or a minimum number of years of residence in Sri Lanka; ten years is likely to be sufficient for non-citizens but an alternative is to offer the pension to everyone with legal residence in Sri Lanka.

Universal non-contributory pensions are becoming increasingly common internationally in both developed and developing countries. The first pension of this type to be implemented was the New Zealand Superannuation in 1940 and it continues to this day for everyone over 65 years old. In 1958, Mauritius became the first developing country to establish a universal pension, currently paying US\$93 per month to everyone over the age of 60 . More recently, universal pensions have been established in places as disparate as Botswana, Namibia, Nepal, Bolivia, Brunei and Kosovo (see Table 1 and Annex A).

Universal pensions function as the foundation pillar of the broader pension system, upon which other pension pillars can be built, whether they be mandatory or voluntary contributory schemes. For example, in New Zealand, a range of voluntary savings schemes also exist into which those who are better-off pay contributions with the aim of achieving consumption-smoothing over their life cycle, although many 
people use these savings simply to pay off their mortgage and other debts in preparation for retirement. Mauritius has taken a different approach by putting in place a mandatory contributory pension for those in the formal sector. However, the success of the contributory schemes in both countries is underpinned by the existence of a universal non-contributory foundation pillar.

\section{Table 1. Universal age pensions around the world ${ }^{3}$}

\begin{tabular}{|l|c|c|c|}
\hline $\begin{array}{l}\text { Country } \\
\text { (from: year) }\end{array}$ & $\begin{array}{c}\text { Qualifying } \\
\text { age }\end{array}$ & $\begin{array}{c}\text { Pension } \\
\text { (\% of per capita GDP) }\end{array}$ & $\begin{array}{c}\text { Benefits transferred } \\
\text { (\% of GDP) }\end{array}$ \\
\hline $\begin{array}{l}\text { New Zealand } \\
(1940)\end{array}$ & 65 & $\begin{array}{c}46 \% \text { (single) } \\
35 \% \text { (with spouse) }\end{array}$ & $\begin{array}{c}4.3 \% \text { (gross) } \\
3.6 \% \text { (net of tax) }\end{array}$ \\
\hline Mauritius (1958) & $60,90,100$ & $16 \%, 60 \%, 68 \%$ & $1.7 \%$ \\
\hline Brunei (1984) & 60 & $10 \%$ & $0.4 \%$ \\
\hline Namibia (1990) & 60 & $16 \%$ & $0.9 \%$ \\
\hline Samoa (1990) & 65 & $22 \%$ & $1.4 \%$ \\
\hline Nepal (1995) & 75 & $10 \%$ & $0.1 \%$ \\
\hline Botswana (1996) & 65 & $10 \%$ & $0.5 \%$ \\
\hline Bolivia (1996) & 65 & $26 \%$ & $1.2 \%$ \\
\hline Mexico City (2001) & 70 & $11 \%$ & $0.2 \%$ \\
\hline Kosovo (2002) & 65 & $50 \%$ & $2.7 \%$ \\
\hline
\end{tabular}

So, what are the advantages of a universal pension over a means-tested pension?

\subsection{A universal pension versus a targeted pension}

The only option to a universal pension in tackling old-age poverty is a targeted pension aimed at the poor. But, is this really a realistic option? Many countries have put in place means-tested pensions for poor older people - including both India and Bangladesh - but one characteristic feature of all of these pensions is their failure to reach large numbers of poor people.

India's National Old Age Pension scheme is well-known for many failings. But, the main problem is the difficulty that poor older people have in accessing the pension and the fact that many of the pensions are captured by those who are better-off. Figure 3 shows how only $45 \%$ of pensions in India actually reach the poorest $20 \%$ of older people, who are meant to be the beneficiaries; in contrast, $55 \%$ are captured by those who are better-off. The reasons for this poor targeting are manifold. For instance, politicians and local officials often distribute pensions as favours while poor people frequently have to pay officials for the pensions or are forced to go through very long and difficult administrative processes. A similar story can be found in Bangladesh.

\footnotetext{
${ }^{3}$ Source: Willmore (2007)

${ }^{4}$ Nepal has recently announced - in September 2008 - that it will be reducing the age of eligibility for its pension to 70 years - and 60 years in one area of the country - and increasing the size of the benefit to $25 \%$ of GDP per capita. Pensions will also be paid to all widows over the age of 60 .
} 
Figure 3. Proportion of means-tested pensions in India accruing to each quintile ${ }^{5}$

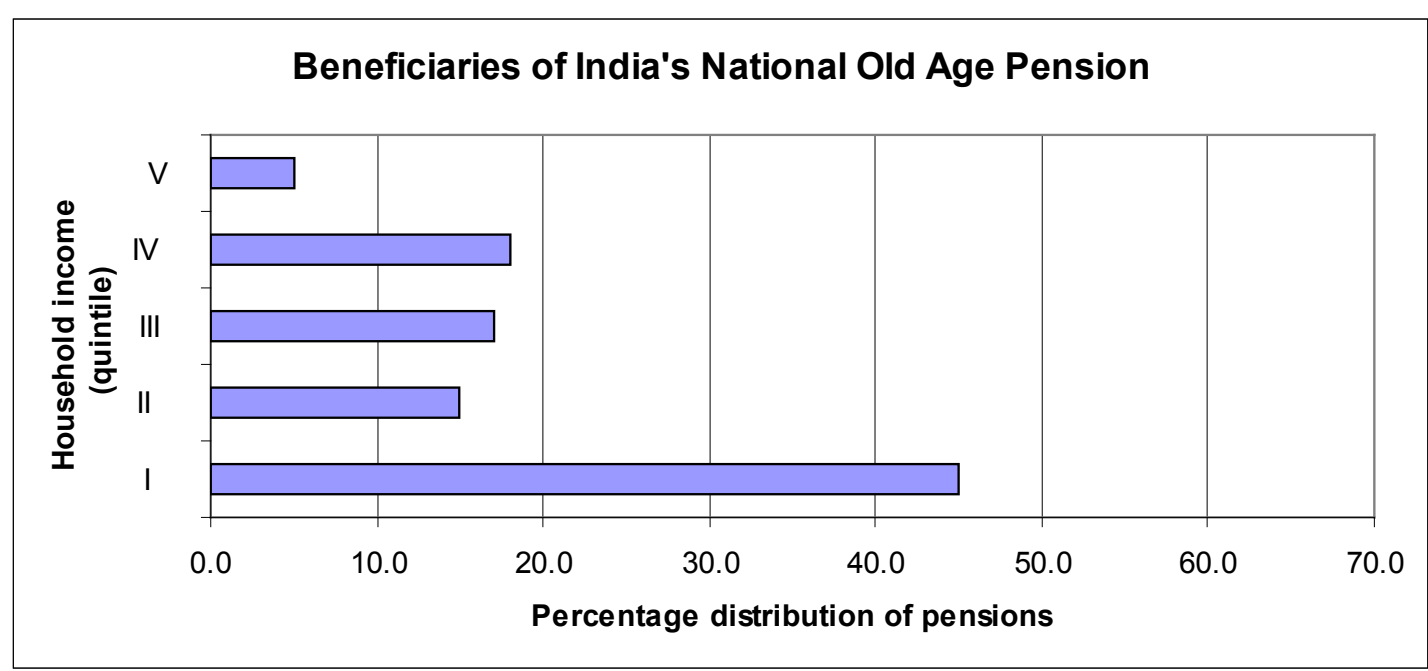

However, it is not just in countries with weak administrative structures that meanstested programmes struggle to reach the poor. In Chile, for example, which has a relatively strong administration, its means-tested pension has also not been particularly effective in reaching poor people. As Figure 4 shows, only $60 \%$ of pensions in Chile reach those in the poorest quintile - it was targeted at the poorest $15 \%$ of older people - while $40 \%$ of benefits were captured by the better-off (Arenas de Mesa and Mesa-Lago 2006). Even in the UK - with very strong administrative structures $-40 \%$ of eligible older people are unable to access means-tested benefits.

Figure 4. Proportion of means-tested pensions in Chile accruing to each quintile $^{6}$

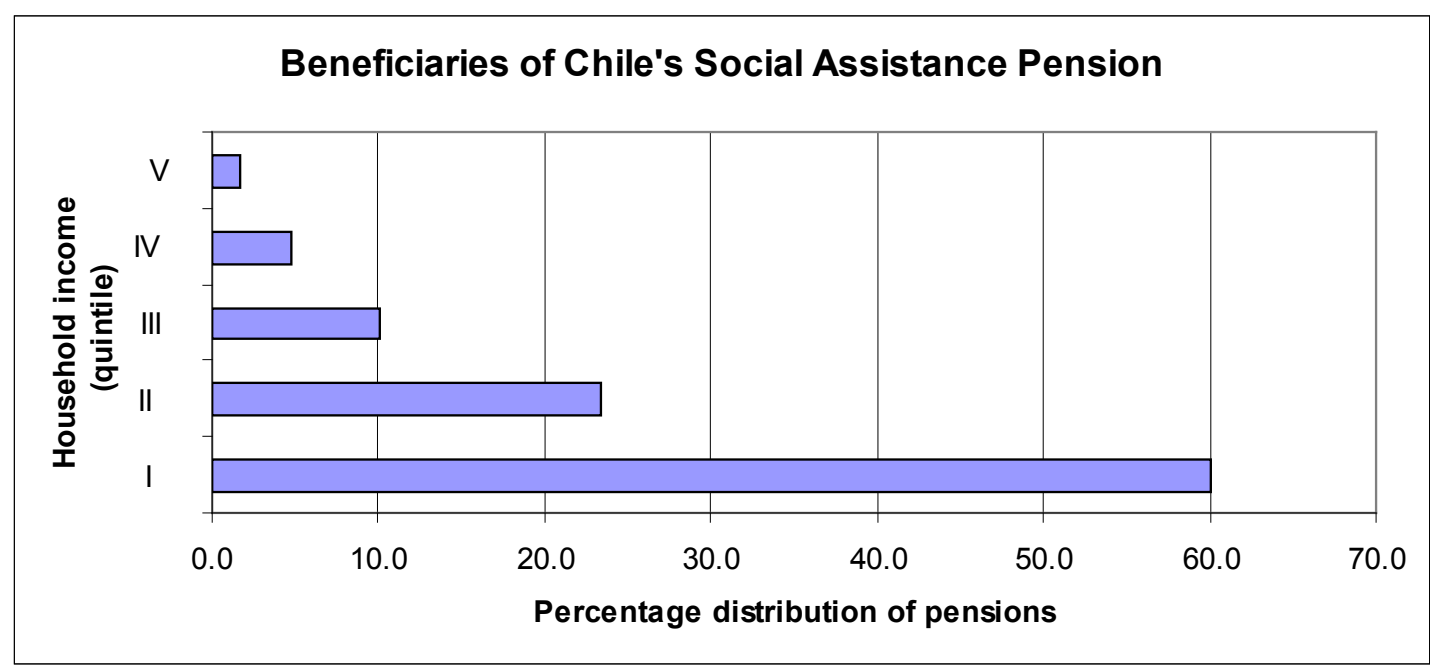

The poor targeting of the Samurdhi system suggests that it would be naïve to expect that a means-tested pension in Sri Lanka could ever be well-targeted. It is highly

\footnotetext{
${ }^{5}$ Source: Grosh et al. (2008, p. 88)

${ }^{6}$ The Social Assistance Pension was supposedly reserved for the poorest $15 \%$ of the $65+$ population. The calculations assume that the $65+$ population is evenly distributed by income quintile. Source: Calculated from Arenas de Mesa \& Mesa-Lago (2006, table 6, p. 161).
} 
likely that a means-tested pension in Sri Lanka would merely replicate the unfortunate experience of both India and Bangladesh.

In contrast, international experience demonstrates that universal pensions, given that they reach almost all older people, provide excellent coverage of the poor and those who are in danger of falling into poverty. In Sri Lanka, there is no reason to assume that a universal pension would not be able to reach almost $100 \%$ of poor older people.

There are also additional factors militating against the adoption of means-tested pensions in developing countries:

High administrative costs Means-tested pensions have very high administrative costs when compared to universal pensions. This is the result of having to invest a lot of time and effort into identifying the poor. And, the more effective a means-tested pension is in reaching the poor, the higher the costs. In Sri Lanka, the administrative costs of a well-targeted means-tested pension would be very high. In contrast, it is very easy to identify those eligible for a universal pension, thereby keeping down administrative costs significantly.

Rewarding cheating and penalising honesty Means-tested pensions reward cheating and penalise honesty. They encourage people to hide their true income and wealth. Those who are honest in declaring their wealth find that they lose out in accessing means-tested pensions. Those who lie and cheat are often rewarded. This is one of the main reasons why Mauritius moved from a means-tested to a universal pension (see Annex A).

Creating perverse incentives Means-tested pensions create perverse incentives and encourage people to act in ways that can harm their best-interests and those of the country. People are discouraged from saving for old age thereby undermining contributory pension schemes (receiving a contributory pension in old age would disqualify someone from the means-tested pension). And, of course, means-tested pensions discourage older people from continuing to work. Universal pensions do not put in place any disincentives. In contrast, people are more likely to save for old age thereby strengthening the contributory pension system - and to continue to work once in receipt of a pension.

Disempowering older people Means-tested pensions disempower older people by placing decisions on their income in the hands of bureaucrats and politicians. Government officials decide who receives the pension and this can place them in a significant position of power over older people. As a result, older people often find that they have to pay government officials if they are to receive a pension or promise to support local politicians in elections. In contrast, a universal pension is often regarded as an entitlement and, given that age is the only qualification, decisionmaking power is taken out of the hands of bureaucrats.

Politically unpopular Means-tested pensions are not popular politically with the wider population. Removing a majority of the electorate from benefits reduces the appeal of a pension scheme and makes it difficult to collect the taxes needed to finance it. And, as has been seen in many countries, continuous denunciations in the media of the corruption associated with means-testing can undermine the popularity of schemes and cause difficulties for governments. In contrast, universal pensions because they are paid to everyone - are very popular politically, particularly among those who have paid their taxes. 
Means-testing as a form of taxation Means-tests are a form of taxation, but it is taxation that weighs heaviest on the poor. Suppose a benefit is provided only to those older people who live in households with income below the poverty line. For a household living just below the poverty line, even a small increase in earned income will cause it to lose the benefit. Total household income - including the social assistance pension - could even decrease following a pay rise for the breadwinner of the family. The implicit rate of taxation on additional earnings, in other words, could well exceed $100 \%$ for families living just below the poverty line.

There are, of course, a range of alternative targeting mechanisms, some of which are simpler than audits of family income and assets, such as denying a non-contributory pension to all those who have ever filed income tax. However, such forms of targeting have significant flaws, including the fact that they require excellent recordkeeping to function well while also building many perverse incentives into the system. ${ }^{7}$

Another way to reduce the overall fiscal costs of a non-contributory pension is to limit it to those who do not already have a pension. Alternatively, the size of the transfer that is given to those who have another state pension could be reduced. This is often referred to as pensions-testing or the provision of a guaranteed minimum pension. In a Sri Lankan context, this would require limiting the access of beneficiaries of the PSPS to the universal pension. However, this would reduce the political popularity of the pension, increase administrative complexity and costs with very little saving to the overall budget, and could be regarded as a tax on retired civil servants. ${ }^{8}$ In fact, the PSPS could be classified as deferred wages rather than a pension which would make withdrawing the universal pension from civil servants even more unjust.

One concern voiced by opponents of universal pensions is that those who are betteroff are eligible to receive a benefit. However, this should not be regarded as a concern; in fact, it could even be seen as a positive factor. In addition to removing the disadvantages associated with means-testing, it needs to be remembered that those who are better-off will have paid higher taxes. It is, therefore, legitimate that they receive a benefit that they have paid for. In fact, it could well be argued that a universal pension is a contributory pension since those who benefit from it will have contributed to it through taxation. This was the argument of a Mauritius MP in 1958 when arguing in parliament in favour of a universal pension (see Box 1).

Furthermore, including all citizens in a non-contributory pension will increase its political popularity, with clear benefits for the political party that introduces the pension.

\section{Box 1: Argument of Mauritius MP F S Chaudian, $1957^{9}$}

"The old age pensioner has throughout the years paid taxes on commodities he has consumed as everybody else has. He has paid taxes on tea, sugar, tobacco, matches, rice, pulses, dried fish, rum, calico, khaki, everything he has consumed and used to be able to live as a useful member of our society. One way or

\footnotetext{
${ }^{7}$ For a more detailed discussion of rule-based targeting, see Annex B.

${ }^{8}$ For a more detailed discussion of the problems associated with this form of means-testing, please see Annex C.

${ }^{9}$ Source: Willmore (2003)
} 
another he has contributed to the national budget. The Old Age Pension scheme being financed out of public funds is [thus] a contributory one. The applicant for Old Age Pension has already paid in his contributions."

In reality, those who are better-off often do not, in fact, bother to collect the universal pension because it is too small to make the effort. In Nepal, for example, the lowest rates of take-up of the universal pension are in Kathmandu, precisely for this reason.

The World Bank agrees that the advantages of a universal pension are clear, as explained in its now-classic publication Averting the Old Age Crisis (1994, p. 240):

"Administratively, this is the simplest structure, with the lowest transaction costs, for the public pillar - an important advantage in developing countries with limited institutional capacities and incomplete record-keeping systems. It avoids the disincentive to work and save inherent in means-tested plans. Its universal coverage helps ensure that the poverty reduction objectives are met, [and] provides a basic income for all old people."

A more recent - 2005 - World Bank report re-affirms this view, stating that a universal age pension "is probably the best way to provide poverty relief to the elderly. Considering the difficulty of identifying who among the elderly is poor, the principal merit of the program is that its universality avoids the targeting issue" (Holzmann et al., 2005, p. 95).

The one advantage of a means-tested pension over a universal pension is that the overall fiscal cost is cheaper than a universal pension. This is the only real positive feature that the World Bank can offer for means-testing (Holzmann et al. 2005, p. 96). However, it comes at the cost of a pension that is ineffective in guaranteeing a minimum income and which creates all the problems outlined above.

\subsection{Reform of contributory pensions in Sri Lanka}

A discussion of the reform of Sri Lanka's contributory pension schemes is beyond the scope of this paper. However, reform is necessary and it should take place once an effective universal pension has been put in place. The existence of a strong universal foundation pillar will enhance the chances of a successful reform of contributory pensions taking place. At the very least, it will remove any chance of non-contributory benefits creating disincentives to save in contributory pension schemes.

However, one possible solution to the challenges raised by the existing informal sector contributory pensions is for them to focus on 'gap coverage'. In other words, they could provide a retirement income not for a lifetime but, rather, for the five or ten years prior to the age at which a member of the scheme qualifies for a universal pension. So, if a universal pension were introduced at 70 years of age, the contributory pension could cover the period from 60-70 years. This could also lead to a higher level of benefit being paid from these schemes than the current very low pensions of 500 or 1,000 rupees a month (or, indeed, it may make these pensions more affordable). 
A universal pension for Sri Lanka

Private initiatives such as the National Savings Bank's 'Pension+' scheme could offer similar coverage for 'gap years' of workers in the informal sector (Anonymous 2008). 


\section{Impacts of non-contributory pensions - international experience}

Universal pensions across the world have been very successful in addressing their main purpose: tackling poverty in old age. New Zealand, as a result of its universal pension, has been the most successful developed country in eliminating poverty in old age (Kidd and Whitehouse 2008). Similar impacts can be found in developing countries. In South Africa, a non-contributory pension which reaches $85 \%$ of the population has been responsible for reducing the poverty gap by $57 \%$ among households containing an older person (see Figure 5). Similarly, in Mauritius, the poverty rate among households containing an older person would be $30 \%$ compared to the current $6 \%$ in the absence of the universal pension (Kaniki 2007). In Lesotho, the percentage of older people who report that they 'never go hungry' has increased from 19 per cent before the pension to 48 per cent after the non-contributory pension which reaches almost all older people was introduced (Croome and Nyanguru 2007).

Figure 5: Impact of the non-contributory pension on poverty in South Africa ${ }^{10}$

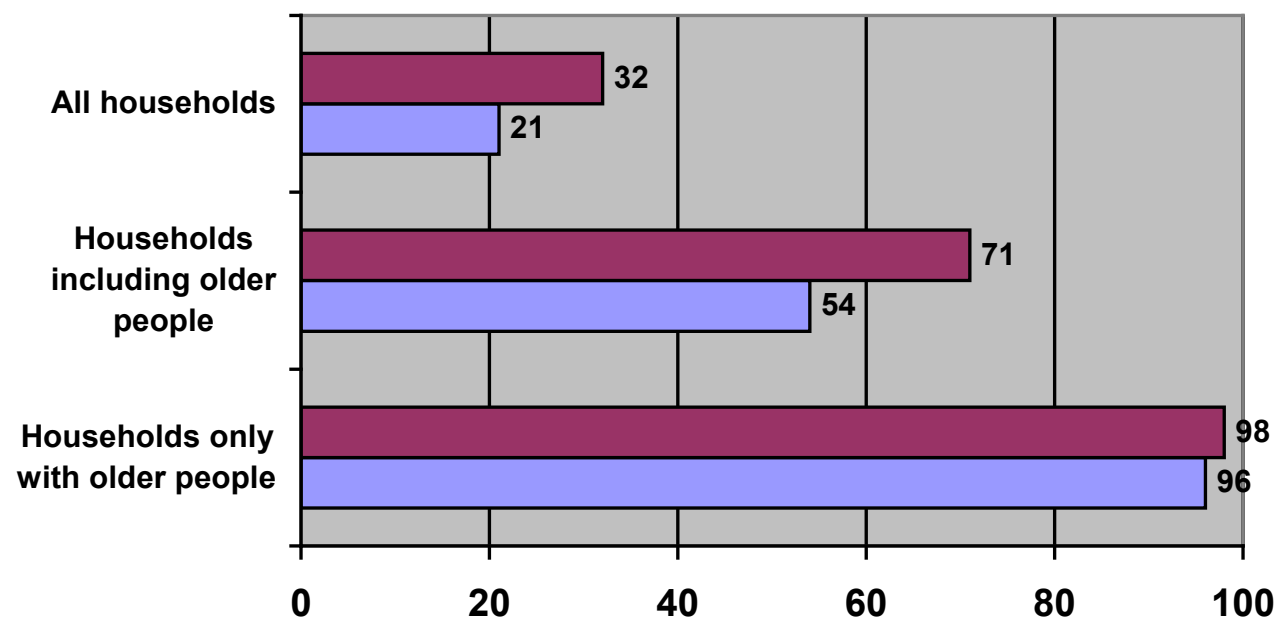

$\square \%$ Poverty Gap Reduction $\quad \square \%$ Destitution Gap Reduction

Interestingly, pensions have also been shown to have an impact on children's wellbeing. There have been observed significant improvements in children's height resulting from pension payments in both South Africa and Brazil. Girls in households containing an older person receiving a pension are $3-4 \mathrm{~cm}$ taller than girls in other households, largely as a result of improved nutrition (Barrientos and Lloyd-Sherlock 2002). In the same countries, it has been observed how the pension has also been associated with an improvement in children's access to education. In South Africa there has been an $8 \%$ increase in school enrolment among the poorest $20 \%$ of households (Samson 2004).

There are three main reasons why pensions benefit children: 1) older people themselves share their pension with children; 2) families no longer have to pay the

\footnotetext{
${ }^{10}$ Source: Samson (2006)
} 
cost of caring for older people and can channel their other income to children; and, 3) working adults do not face the same pressures to save for old age and can spend their limited income on their children.

Pensions can also support older people and their families in increasing their productivity. In the absence of regular and predictable cash transfers, poor older people and their families live lives that are highly uncertain. They do not know whether they will be able to eat tomorrow, next week or next month. As a result, they are unable to plan for the future or manage the risks and shocks that occur in their lives. Pensions provided by the state can put predictability into the lives of poor older people and their families by offering them a guarantee of a minimum standard of living for themselves and their families. And, there is increasing evidence that this transforms the economic behaviour of poor families. They can plan for the future with a degree of certainty and are more likely to engage in productive activities.

For example, in one cash transfer scheme in Zambia - which is aimed mainly at households headed by older people - beneficiaries have invested 29 per cent of the US $\$ 7$ per month they receive in activities such as agriculture and animal-rearing. As a result, seven times as many households own goats (MCDSS/GTZ 2005). Similarly, in South Africa, pensions have enabled increased access of families to credit and capital equipment. ${ }^{11}$ Of course, this effect is much less likely with a means-tested pension because of the disincentives to work and invest that such schemes create. ${ }^{12}$

There is also good evidence that injecting cash through a non-contributory pension can act as a stimulus to local economies. In Lesotho, around $18 \%$ of cash from the pension is spent on activities that create jobs for others (Croome and Nyanguru 2007). In Namibia, the universal pension has acted as a vital stimulus to local markets in rural areas. According to the International Labour Organization, in Namibia, 'the wheels of the local economy begin to turn on pension day.' In fact, it has been estimated that, in the absence of the pension, up to half of the shops in many rural areas of Namibia would close. ${ }^{13}$

Importantly, universal pensions can help build social cohesion in countries and create a positive investment environment, as well as encouraging people to work. Forty years ago, Mauritius had a mono-crop economy, high poverty rates and significant racial tension. Today, Mauritius has the lowest poverty rate in Africa. An IMF paper recognises that the pension played a role in strengthening the social contract between government and citizens, thereby creating greater acceptance of the government's economic policies. ${ }^{14}$ In Botswana, the universal pension, introduced in 1996, has been a very effective mechanism for tackling the high levels of inequality in the country and promoting social stability thereby supporting social cohesion in Africa's fastest-growing economy (Samson 2007). And, in South Africa, the decision by the African National Congress to extend the pension equitably to all citizens following the fall of the apartheid regime helped facilitate the healing process in the post-apartheid period.

In Sri Lanka, a universal pension could contribute significantly to the peace process and strengthen the social contract as it would be distributed by government to everyone, regardless of their ethnicity. Means-tested pensions are much less likely to

\footnotetext{
${ }^{11}$ Lund (2002), Ardington and Lund (1995)

12 The Zambia programme is in fact means-tested. However, at the time of these results, beneficiaries were not aware that they could be removed from the scheme.

${ }^{13}$ Devereux (2001)

14 Subramanian and Roy (2001)
} 
contribute to social cohesion as their distribution can be more easily manipulated to favour one group over another.

Finally, however, and of greatest significance, a universal pension can restore dignity to many older people who now live in deep poverty and are often treated as a burden by their families. In north-east Brazil, the provision of pensions has restored older people - who had been increasingly regarded as outcasts - to their position as the most respected people in their community. With a minimum pension, older people no longer have to beg from others to survive and have a greater chance of living out the final years of their lives in peace. 


\section{The fiscal cost of a universal pension}

Universal pensions are clearly the most effective means of guaranteeing a minimum income for all older people, in particular those living in poverty. Yet, despite the fact that many developing countries have successfully implemented universal pensions, some people continue to oppose them on the grounds that they are unaffordable. In Sri Lanka, this argument has been used by Gaminiratne (2004) and the World Bank (2008). But, is this true? This section will calculate the fiscal cost of a universal pension in Sri Lanka and show that it could well be affordable. In fact, it will be demonstrated that its overall cost - in terms of a percentage of GDP - is well within the parameters for other developing countries that have put in place universal pensions.

When determining the cost of a universal pension scheme, two key parameters need to be taken into account: age of eligibility and the size of the grant:

- Age of eligibility (the age at which people become entitled to the pension) the higher the age, the fewer the numbers that are eligible, and the lower the overall cost of the scheme.

- Size of grant (the cash amount provided to beneficiaries) - the lower the size of the grant, the lower the overall cost of the scheme.

In addition, calculations of overall cost need to incorporate the costs of administration. The calculations below also include the cost of a funeral benefit.

\subsection{Age of eligibility}

The study calculates the costs of a universal pension to four alternative qualifying ages: all those over-60, over-65, over-70 and over-75. The number of potential pensioners using 2007 population estimates ranges from 509,000 at age $75+$ to 2.2 million at age $60+$ (see Table 2$)$.

\subsection{Size of grant}

A universal pension should be large enough to provide a penniless beneficiary with enough income to survive with minimum dignity. What is considered sufficient to meet basic needs varies with the average income and social norms of each country. Calculations on the cost of the grant will use the Sri Lanka National Poverty Line. This was calculated for 2002 as 1,423 rupees (US\$15) a month, equal to $20.5 \%$ of per capita GDP in that year (Sri Lanka DCS, 2004). ${ }^{15}$ The poverty line is a measure of absolute poverty, not relative poverty, so it becomes a smaller fraction of per capita GDP as the economy grows.

Although the National Poverty Line has not changed in real terms since 2002, each month its nominal value is adjusted by the Colombo Consumer Price Index (CCPI) so

\footnotetext{
${ }^{15}$ More than two-thirds of the 2002 National Poverty Line (973 rupees) was needed to purchase food to provide 2,030 kilocalories a day. The remainder was budgeted for non-food consumption.
} 
that its purchasing power remains approximately constant. In 2007, the monthly average was 2,321 rupees - equivalent to $15.5 \%$ of per capita GDP. It has continued to rise in $2008^{16}$ (see figure 6).

Figure 6. Sri Lanka's National Poverty Line, 2003-2008 ${ }^{17}$

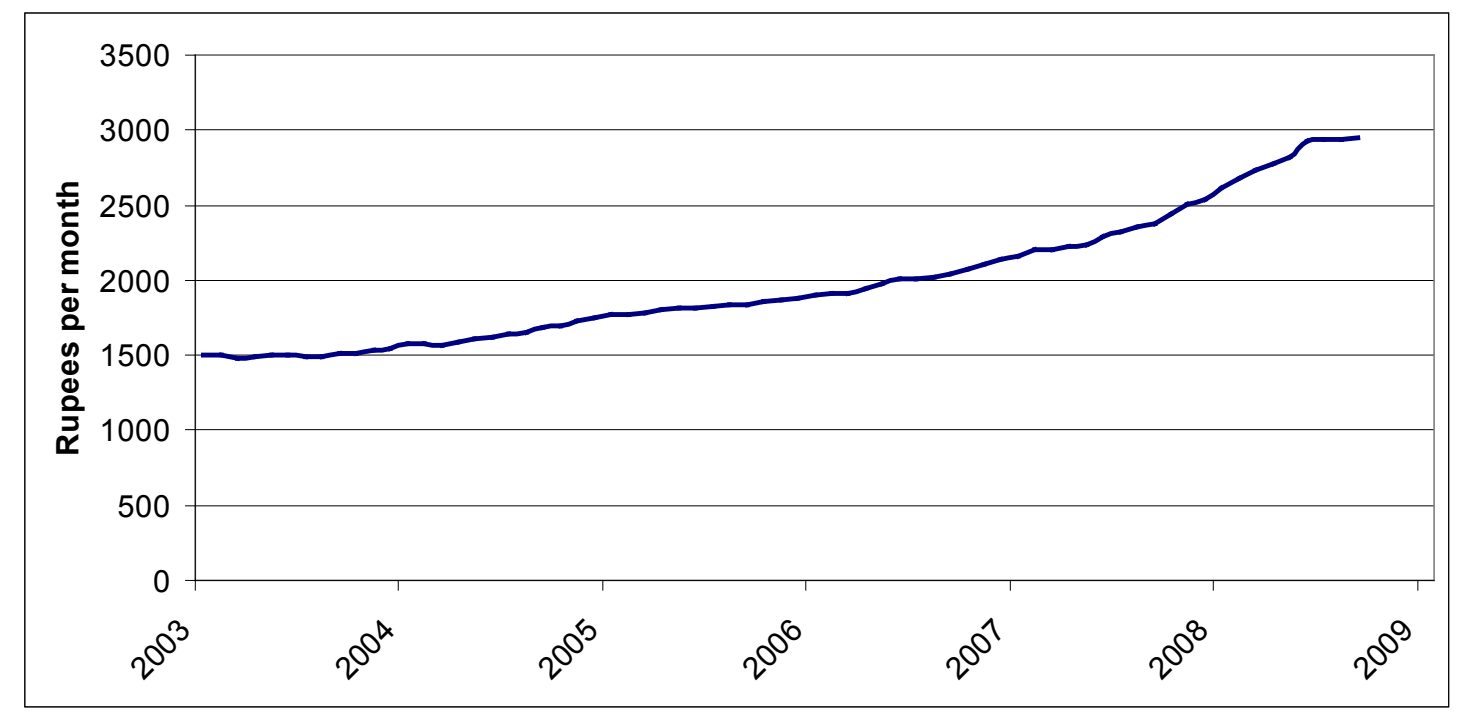

Since the National Poverty Line is the target benefit for a universal pension in this study, the cost of the pension will be calculated using the 2007 figure of 2,321 rupees (US\$21). In September 2008 prices, this would provide a benefit of 2,948 rupees (US\$27) per month. A figure of $15.5 \%$ of GDP per capita for a universal pension is well within the norms of international experience; in fact, it is probably on the low side and will become lower over time if benefits are adjusted only for price inflation and not for increases in per capita income.

\subsection{Administrative costs}

Calculations of the overall cost of a universal pension need to take into account the cost of administering the pension. In this study, administrative costs have been estimated at $5 \%$ per year, in line with international practice. ${ }^{18}$ Administrative costs are low because universal pensions are by far the simplest and least expensive social transfer programmes to manage. There is, for example, no need to keep a record of contributions because individual contributions are not required; and, there is no need to audit income and assets of potential pensioners or close relatives because benefits are not means-tested.

\footnotetext{
${ }^{16}$ In September of 2008 the National Poverty Line reached 2,948 rupees, roughly US $\$ 27$ a month, but it is the same poverty line of 2002, with the same purchasing power. It is more than double the 2002 figure of 1,423 rupees only because prices more than doubled over this period.

${ }^{17}$ The National Poverty Line is constant at 1,423 rupees a month in 2002 prices. It increases only because of price inflation. Source: Sri Lanka DCS $(2004,2008)$.

${ }^{18}$ Botswana's universal pension has an administrative cost of $4.5 \%$ and Mauritius's is between $2 \%$ and $3 \%$ (Fultz and Pieris 1999). The South African pension has an administrative cost of $6 \%$ but, given that it includes a means test, this will have inflated its costs compared to a universal pension.
} 
The estimate of administration costs for Sri Lanka is an absolute maximum and it is likely that costs could be much less, given the feasibility of relatively cost-effective payment options available (these are discussed below).

\subsection{Funeral benefit}

To encourage families to report the death of a pensioner, it can be useful to pay a funeral benefit. The value of a funeral benefit is included in the overall cost of a pension and is equivalent to the cost of three months of the pension grant: 6963 rupees. Estimated funeral benefits in table 2 assume that $4.5 \%$ of the $60+$ pensioners, $5.9 \%$ of the $65+$ pensioners, $7.8 \%$ of the $70+$ pensioners and $10.5 \%$ of the $75+$ pensioners die during the year.

\subsection{Fiscal costs of the universal pension in 2007}

The total cost (for 2007) of the pension benefits are presented in Table 2. For each age group they are:

- Age 75+: $0.4 \%$ of GDP or 15.311 billion rupees (US $\$ 138$ million)

- Age 70+: $0.8 \%$ of GDP or 26.961 billion rupees (US $\$ 244$ million)

- Age 65+: $1.2 \%$ of GDP or 42.459 billion rupees (US\$384 million)

- Age $60+: 1.8 \%$ of GDP or 64.308 billion rupees (US $\$ 581$ million)

In deciding the age of eligibility with which to commence a pension, it may well be prudent to choose a higher age initially, with the intention of reducing the age over time as the programme becomes politically more popular and funding possibilities increase. However, it is important not to start the age too high as the number of older people covered may be too small for the impact of the pension to be meaningful.

Consequently, it may be sensible in Sri Lanka to aim to commence a universal pension for everyone over 70 years of age, with the aim of reducing the age progressively to $65+$ over the next ten years. A pension for everyone over the age of 70 would, therefore, cost $\mathbf{0 . 8 \%}$ of GDP, which corresponds to $4.3 \%$ of current government expenditure. 
A universal pension for Sri Lanka

Table 2. Fiscal cost of a universal pension, Sri Lanka $2007^{19}$

\begin{tabular}{|c|c|c|c|c|}
\hline & \multicolumn{4}{|c|}{ Universal pension from age } \\
\hline & 60 & 65 & 70 & 75 \\
\hline \multicolumn{5}{|l|}{ Average monthly benefit } \\
\hline - Sri Lankan rupees & 2321 & 2321 & 2321 & 2321 \\
\hline - US dollars & 21 & 21 & 21 & 21 \\
\hline - \% of per capita GDP & $15.5 \%$ & $15.5 \%$ & $15.5 \%$ & $15.5 \%$ \\
\hline Beneficiaries (thousands) & 2166 & 1427 & 903 & 509 \\
\hline Total pension benefits (million rupees) & 60567 & 39851 & 25187 & 14210 \\
\hline Total funeral benefits (million rupees) & 679 & 586 & 490 & 372 \\
\hline Administrative expenses (million rupees) & 3062 & 2022 & 1284 & 729 \\
\hline \multicolumn{5}{|l|}{ Fiscal cost } \\
\hline - million Sri Lankan rupees & 64308 & 42459 & 26961 & 15311 \\
\hline - million US dollars & 581 & 384 & 244 & 138 \\
\hline - \% of GDP & $1.8 \%$ & $1.2 \%$ & $0.8 \%$ & $0.4 \%$ \\
\hline - $\%$ of current government expenditure & $10.1 \%$ & $6.8 \%$ & $4.3 \%$ & $2.5 \%$ \\
\hline
\end{tabular}

\subsection{Initial set-up costs}

Initial set-up costs of the pension will be higher than normal operating costs. Key tasks include:

- Detailed design of the pension scheme

- Capacity building of staff to administer the pension

- Developing the software with which to manage the beneficiary database

- Initial registration of the pensioners

- Building an effective payment system.

It is difficult to estimate these costs with accuracy, but one week's benefit payments as of September 2008 at 2,936 rupees (US\$27) per applicant - should be more than adequate to cover these extraordinary expenses. This would be a total cost of approximately US\$6 million. A week's delay in initialising benefit payments will generate these funds. Any money that is not needed to pay set-up costs could be retained in a Universal Pension Fund for future use (see Section 6 below for further explanation of this potential fund).

\footnotetext{
${ }^{19}$ Source: Calculations based on population data from De Silva (June 2007).
} 


\subsection{Comparison of Sri Lanka costs with international experience}

How does a universal pension transferring benefits that total $0.7 \%$ of GDP - for a pension for everyone over 70 years of age - compare to international practice ${ }^{20}$ In reality, this is on the low side. As Figure 7 shows, transfers of GDP via universal pensions across developing countries range from $0.4 \%$ in Brunei to $2.7 \%$ in Kosovo. ${ }^{21}$ However, most are in the range of $0.9 \%$ to $1.7 \%$ of GDP, making a proposed universal pension in Sri Lanka for everyone over 70 years one of the least costly pensions internationally (in relative GDP terms).

Figure 7. Transfers via universal pensions as percentage of GDP - international experience $^{22}$

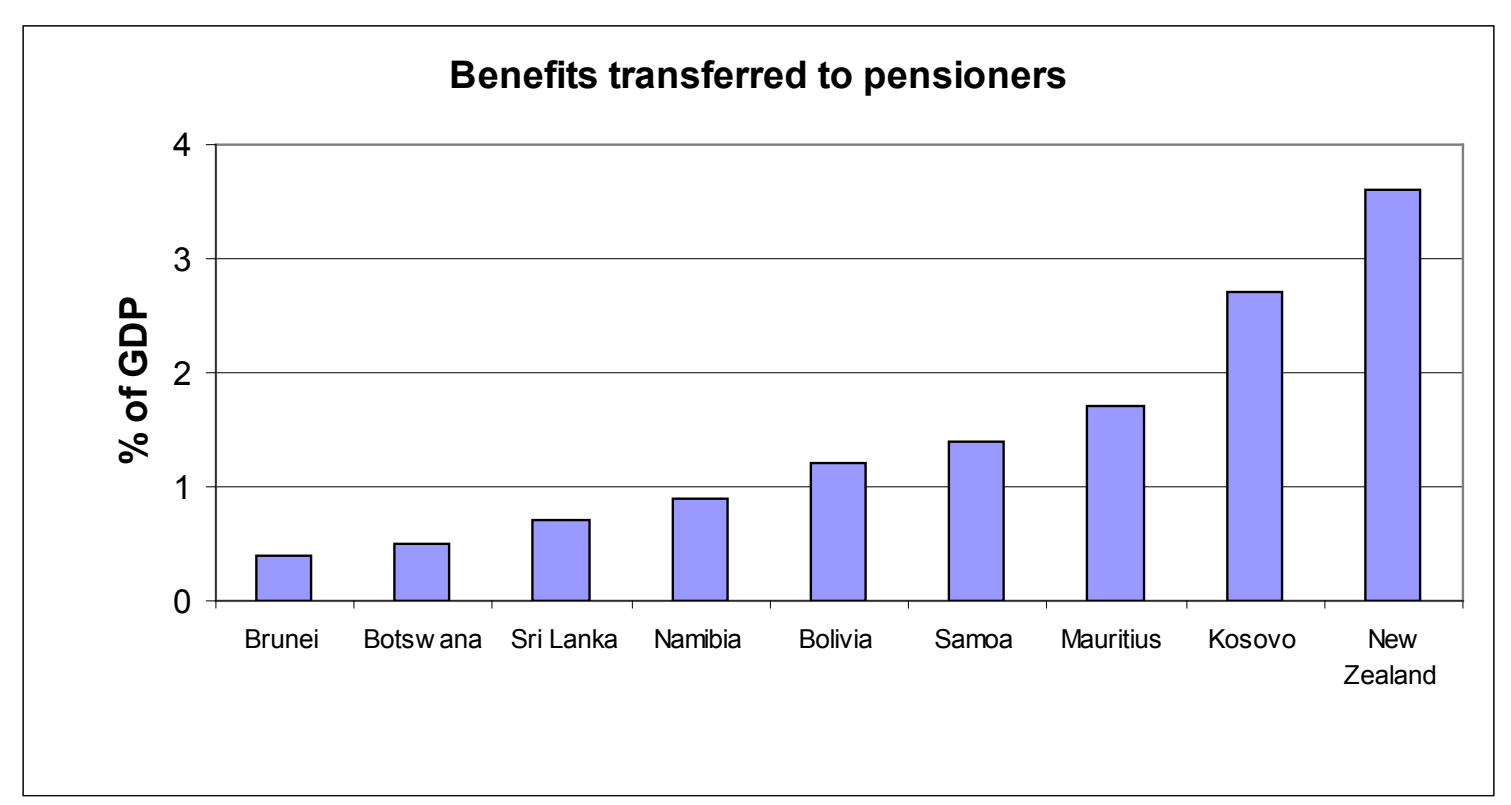

It is of particular interest to compare Mauritius and Sri Lanka, given the proximity across the Indian ocean of the two countries. Although Mauritius today is a prosperous, middle-income country, when it began its pioneering experiment with a universal age pension it was a relatively poor country. In 1958, the per capita GDP of Mauritius was $\$ 4,544$ (in 1996 international dollars). That year Mauritius transferred $1 \%$ of the country's GDP to older people, giving each woman from the age of 60 and each man from the age of 65 a cash benefit equal to $24 \%$ of per capita GDP. Sri Lanka's per capita GDP today, in comparable PPP prices, is higher than that of Mauritius in 1958 (see Figure 8). If Mauritius could afford a universal pension at 1\% of GDP in 1958, it indicates that it should also be feasible in Sri Lanka, if the political will exists.

\footnotetext{
${ }^{20}$ Note that the $0.7 \%$ of GDP refers only to the costs of the transfers and not the total costs of the pension scheme which would be around $0.8 \%$ of GDP.

${ }^{21} \mathrm{Nepal}$ is not included since the total value of benefits is about to change given the recently announced decision to lower the age of eligibility of the pension to 70 and increase the benefit to US\$7 per month, compared to the current benefit of around US\$2 per month.

${ }^{22}$ Death benefits and administrative expenses are excluded. Entry for Sri Lanka $(0.7 \%)$ assumes a universal pension from age 70 . Source: Table 1.
} 
Figure 8. Mauritius and Sri Lanka compared, 1950-2007 ${ }^{23}$

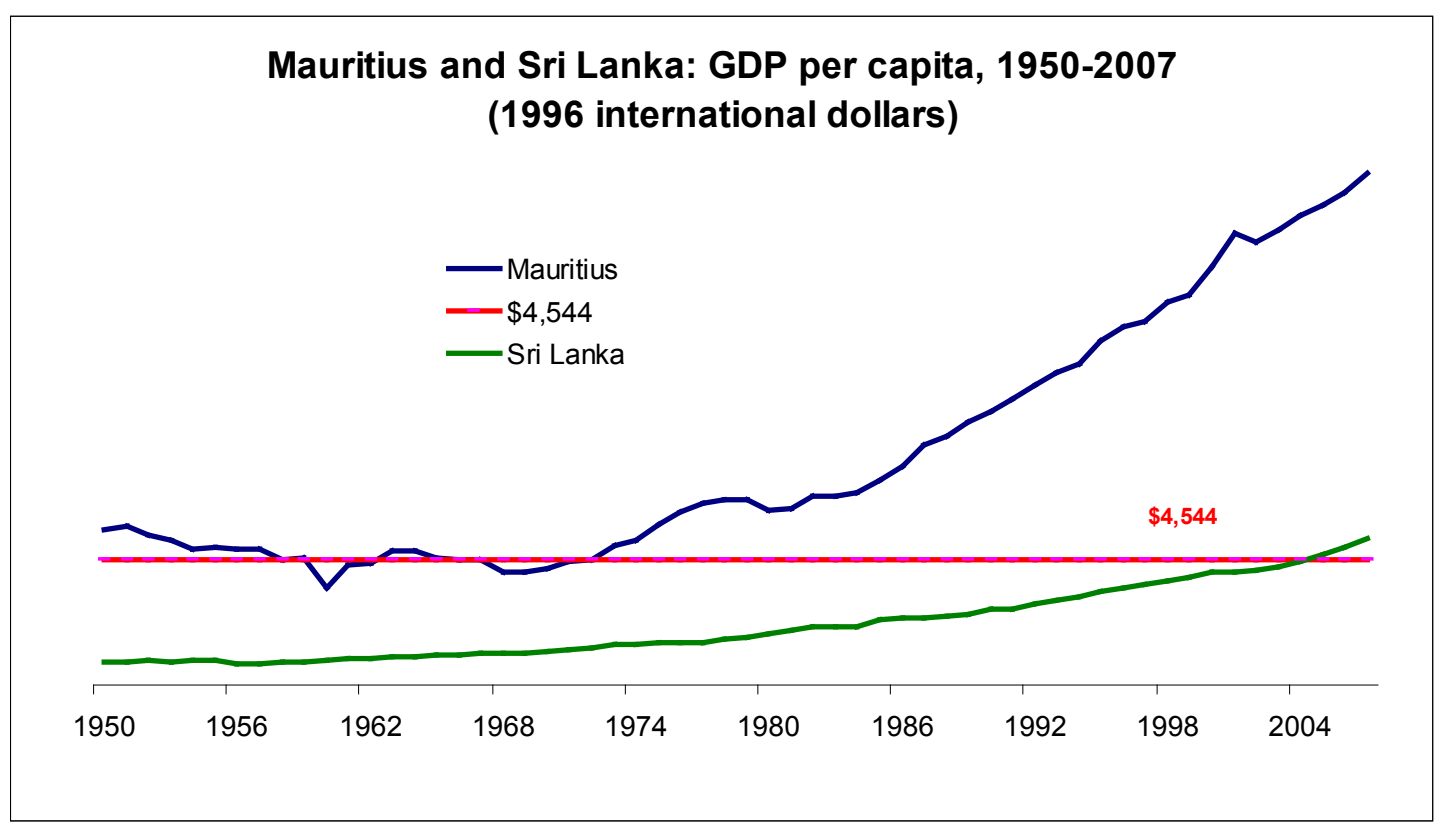

\subsection{Fiscal cost of the Sri Lanka universal pension over time}

Fiscal costs of a universal pension will increase over time as the number of agequalified older people increases. But, providing there is sufficient economic growth, the pension will remain as affordable in the future as it is today. Sri Lanka's GDP grew by an average of $4.8 \%$ a year between 1980 and 2007 , translating into per capita growth of $3.6 \%$ a year. If the $3.6 \%$ per capita trend rate of growth continues, GDP growth to 2041 will average $3.7 \%$ and pension costs, as a percentage of GDP, will actually decline (see Figure 9.) For example, the projected decline in costs for a pension for everyone over 70 years old would be from $0.8 \%$ of GDP in 2007 to $0.6 \%$ in 2041.

Suppose per capita GDP growth slows to one-half its trend rate, to $1.8 \%$ a year. This would cause the fiscal burden of a universal pension to increase, but not significantly (see Figure 10). For example, the costs of a pension for everyone over 70 would rise from $0.8 \%$ of GDP in 2007 to $1.1 \%$ in 2041 . This would still be a relatively low fiscal cost for a universal pension by international standards.

\footnotetext{
${ }^{23}$ Source: Heston, Summers and Aten (2006); estimates for 2003-2007 based on real per capita GDP data from IMF World Economic Outlook Database (April 2008).
} 
Figure 9. Fiscal cost of a universal pension with trend growth, 2007-2041 ${ }^{24}$

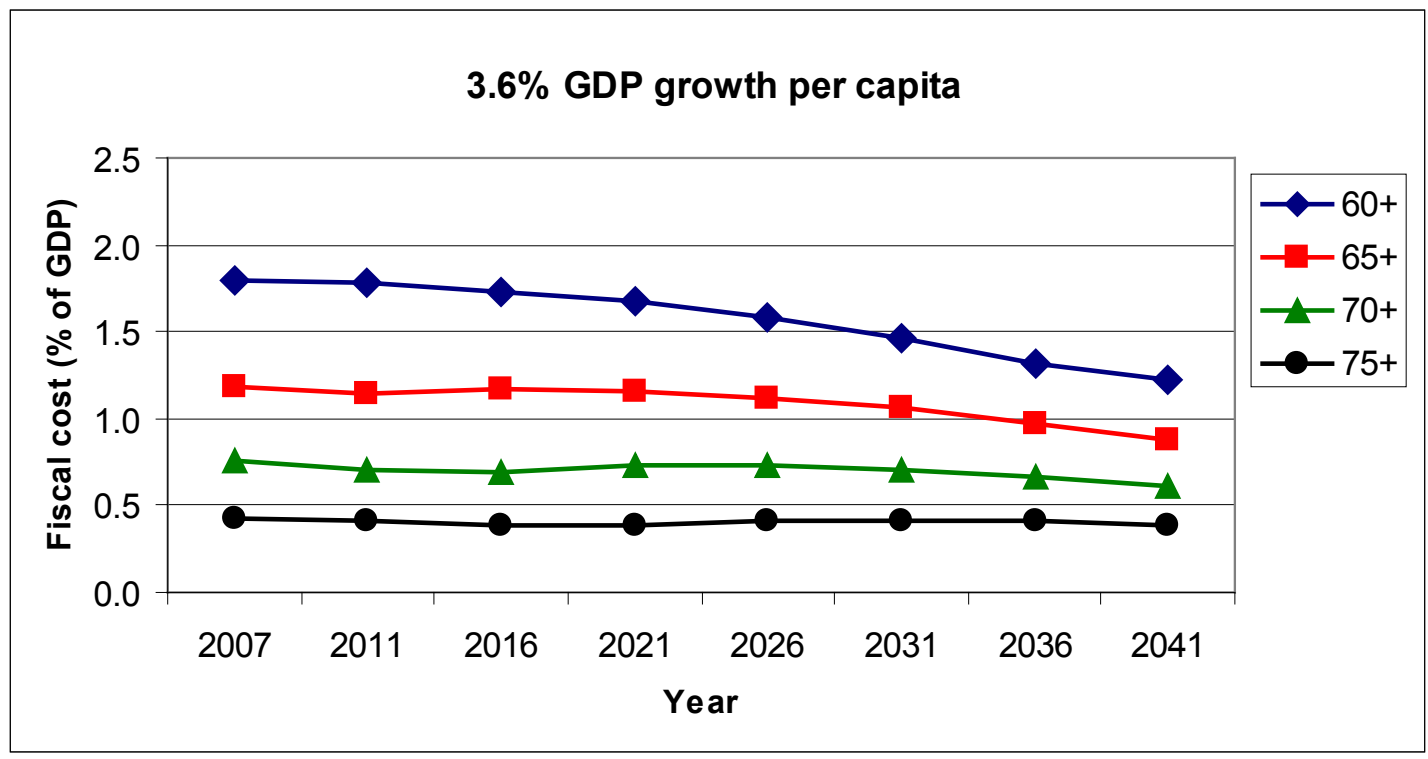

Figure 10. Fiscal cost of a universal pension with slow growth, 2007-2041 ${ }^{25}$

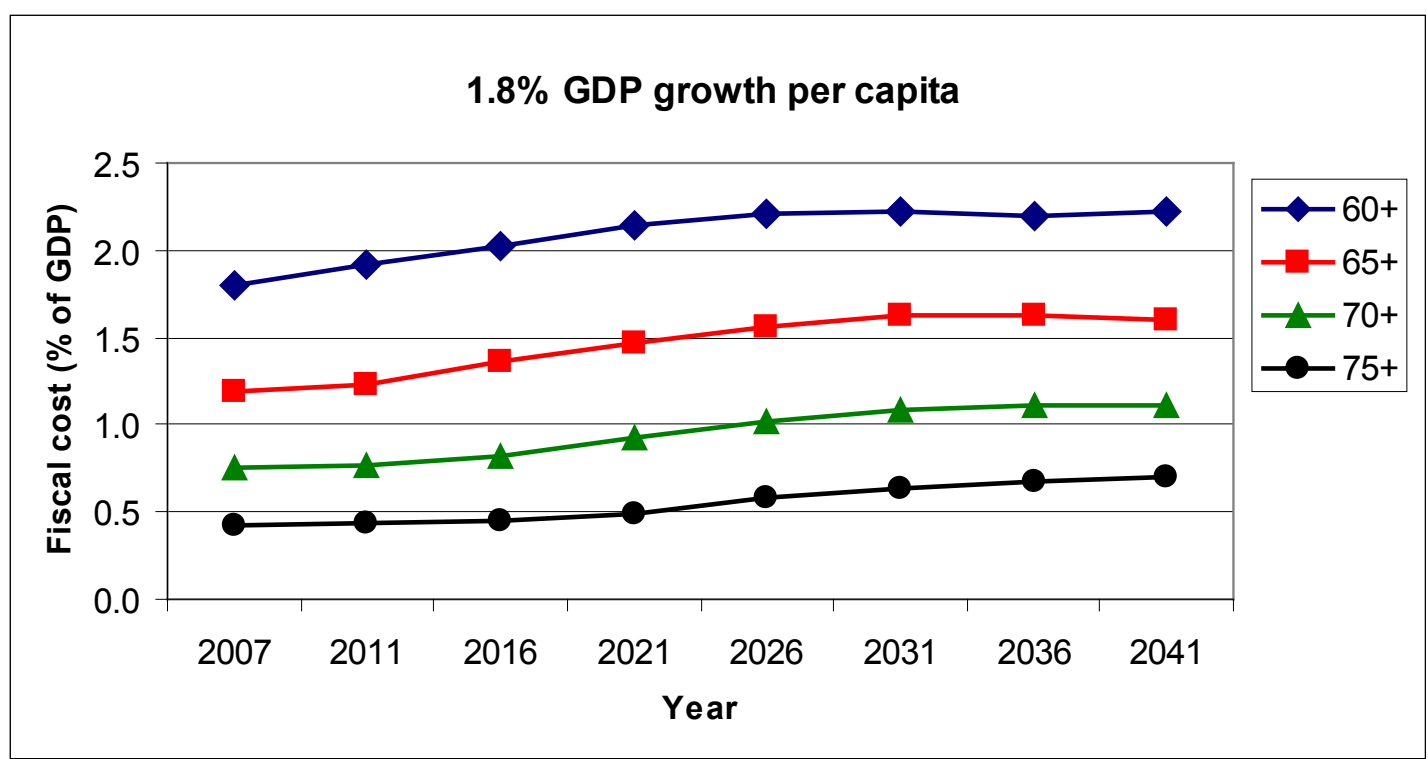

\footnotetext{
${ }^{24}$ The basic poverty-line pension is the same for each age of eligibility: 2,321 rupees a month in 2007, adjusted for price inflation in subsequent years. Fiscal cost includes payments of death benefits and allowance for costs of administration. Source: Annex table D4.

${ }^{25}$ The basic poverty-line pension is the same for each age of eligibility: 2,321 rupees a month in 2007, adjusted for price inflation in subsequent years. Fiscal cost includes payments of death benefits and allowance for costs of administration. Source: Annex D, Table D4.
} 


\section{Financing a universal pension}

Ultimately, the financing of a universal age pension is a question of political will. International experience has demonstrated that, if a government wants to implement a pension, it will be able to find the necessary finance. In 2004, Lesotho put in place a non-contributory pension reaching almost everyone over 70 years of age despite advice against doing so from the World Bank and International Monetary Fund. The pension costs $1.4 \%$ of GDP and has been a tremendous success. It played a major role in securing the recent re-election of the government.

Nonetheless, governments still need to find the necessary finance. One option may be to look for savings in other existing budgets but it is likely that there needs to be some increase in taxation. Taxpayers may be more willing to finance age pensions if the additional taxes required are collected exclusively for the purpose of universal pensions and they are assured that the pension benefits will be protected. Since everyone benefits from universal pensions, it is important that everyone contributes to their finance. The tax, then, ought to have a broad base.

There are limited options in Sri Lanka. Personal income tax might seem a good choice but, in Sri Lanka, as is typical of low-income countries, only a minority of the population pays income tax. Consumption taxes have a broader base than income tax in Sri Lanka so may be a better choice for an earmarked tax ('contribution') to finance a universal pension. How might this work?

In 2007, the Government of Sri Lanka collected 284 billion rupees from the valueadded tax (VAT) and excise taxes. Two-thirds of the revenue was from VAT and the remaining one-third from excise taxes. VAT rates in Sri Lanka range from zero (exempt) to $20 \%$. A small increase in VAT could provide sufficient funding to finance a universal pension. For example, an increase in VAT of $5 \%$ to $5.5 \%$ (along with similar small increases at higher levels of VAT) would pay for a pension for everyone over 70 years. This would imply a surcharge of $9.5 \%$. For lower ages of eligibility the surcharge would, of course, be higher. Table 3 sets this out in more detail. Excise taxes, which are collected largely on consumption of tobacco, liquor and petroleum, would be similarly affected.

Table 3. Financing the universal pension with a surcharge on consumption taxes $^{26}$

\begin{tabular}{|l|c|c|c|c|}
\hline & \multicolumn{4}{|c|}{ Universal pension from age } \\
\hline & $\mathbf{6 0}$ & $\mathbf{6 5}$ & $\mathbf{7 0}$ & $\mathbf{7 5}$ \\
\hline Surcharge & $22.6 \%$ & $14.9 \%$ & $\mathbf{9 . 5 \%}$ & $5.4 \%$ \\
\hline & & & & \\
\hline $20 \%$ VAT becomes & $24.5 \%$ & $23.0 \%$ & $\mathbf{2 1 . 9 \%}$ & $21.1 \%$ \\
\hline $10 \%$ VAT becomes & $12.3 \%$ & $11.5 \%$ & $\mathbf{1 0 . 9} \%$ & $10.5 \%$ \\
\hline $5 \%$ VAT becomes & $6.1 \%$ & $5.7 \%$ & $\mathbf{5 . 5 \%}$ & $5.3 \%$ \\
\hline $0 \%$ VAT remains & $0.0 \%$ & $0.0 \%$ & $\mathbf{0 . 0 \%}$ & $0.0 \%$ \\
\hline & & & & \\
\hline
\end{tabular}

\footnotetext{
${ }^{26}$ The surcharge is on VAT and excise taxes. Source: calculations based on 2007 tax revenue data from Central Bank of Sri Lanka (2008), Table 116
} 
Consumption - and, therefore, taxes on consumption - tends to track GDP. If real economic growth continues its long-run per capita trend, revenue from any of the surcharges reported in table 3 will be adequate to finance the desired pension. In fact, with trend growth, revenue will be more than adequate, providing allowance for a future reduction in the surcharge or increase in benefits. If growth is lower than expected, the additional finance required to fund the pension would be minimal since the main body of funding would be guaranteed.

Funds collected from this additional taxation could be placed directly into a Universal Pension Fund. The existence of this fund - with suitable guarantees built in - should convince the general population that it is worthwhile paying into this fund as it will provide them with a guaranteed pension in old age. As the fund increases in size, the surcharge could be reduced, the size of benefits could be increased, or the age of eligibility for the pension could be reduced. 


\section{Key design and implementation issues}

\subsection{Registration processes}

In order to implement a universal pension, Sri Lanka will need to undertake an initial process to register all those who are over the required 'age of eligibility' for the scheme - as well as those who will become eligible in the near future - and satisfy the necessary residence conditions. This information will then need to be stored on a registry and updated on an on-going basis as new individuals reach the required age, and to remove people from the scheme on their death.

\subsubsection{Establishing eligibility}

Establishing who is eligible for a universal pension is simple because the only information required is proof of age and residence in the country. Most applicants in Sri Lanka will have a national identity card. For those lacking a card, more than 10,000 village elders committees organised by the National Council of Elders can help in verifying the true age of applicants. However, age should not just be verified for applicants. In the short term, it would be useful to verify the ages of anyone who may be eligible for the pension over the next ten years. This would make future registration even easier and it should be linked to a process of extending national identify cards to everyone.

\subsubsection{Process of registration}

When registering people for a pension scheme, it is possible to use either a push or pull mechanism:

- A push mechanism implies that the government itself goes out into the communities to find those who should be on registered for the scheme.

- A pull mechanism implies that potential beneficiaries go to a specific point to register - in other words, potential beneficiaries take the initiative.

A push mechanism is administratively much more expensive than a pull mechanism and would need to be repeated on a regular basis to ensure that new beneficiaries are located.

A pull mechanism is preferable since it reduces costs. In Sri Lanka, registration could be done by local government offices or trained community leaders. The only proof required from beneficiaries would be proof of age, probably linked to the national ID card. While registration would be an administratively heavy task in the months leading up to the introduction of the pension - as it would be desirable to register all beneficiaries prior to the payment of the first pensions - once the pension is implemented the administrative demands will reduce significantly as only a relatively small number of new beneficiaries will come forward each year.

However, a pull mechanism needs to be accompanied by an effective communications strategy so that potential beneficiaries are aware of their right to register for the social pension. Village elders committees could play an important role in ensuring that everyone is aware of their entitlement. 
One way of easing pressure on administration when the registration begins is to allow applicants to receive up to twelve months benefits in arrears, without interest but also without penalty. This will ensure that an older person does not suffer unduly if the registration process is slow, or even if an applicant was late in learning about the new benefit.

\subsubsection{De-registration of beneficiaries}

In a universal pension system, it is only necessary to de-register beneficiaries on their death. Relatives continuing to receive benefits following the death of a beneficiary is one of the biggest fraud risks in any pension system. It should, of course, be made illegal for relatives of beneficiaries not to report the death of a beneficiary. However, the state can also put in place positive incentives to encourage relatives to notify the pension administrators of the death of a beneficiary.

Rather than hire an army of inspectors to police beneficiaries, it is preferable to give a funeral benefit of, perhaps, three months of pension benefits as a lump sum, on condition that a pensioner's death is reported within 20 days. The benefit could be paid to a designated beneficiary or, in the absence of a designated beneficiary, to the person who arranges and pays for the funeral of the deceased. The process could be supported by village elders committees who could assist relatives of the recently deceased in reporting the death.

\subsubsection{Creation of a registry for pension recipients}

The government will need to create a 'registry system' to hold information on beneficiaries and to pass the data to relevant payment providers to enable cash to reach older people on the scheme. A computerised system using advanced software will be the most efficient means of holding information on beneficiaries and it should be directly interfaced with the payment mechanism. The registry should be able to accommodate new registrations for the pension and the removal from the registry of those who have died.

Although the registry will be co-ordinated centrally, it will be most effectively managed if local government offices are able to administer data locally, inputting into the central database.

There will be a number of design options for a registry depending on the payment mechanism chosen and the process which is established for on-going registrations to the scheme. The decision on the form a registry will take would need to be made during the design phase of a pension scheme.

However, rather than developing its own software for a beneficiary data-base, Sri Lanka should, first of all, investigate data-bases used elsewhere. The South African Ministry of Social Development has expressed interest in sharing its technology with other countries and may be willing to export its data-base software to Sri Lanka at little or no cost and, potentially, provide technical advice to adapt it to the Sri Lankan context. Brazil is another country that may be interested in exporting its registration data-base technology. 


\subsubsection{Payment mechanisms}

Regular and reliable payments will be essential to the success of a universal pension scheme in Sri Lanka, including enabling the maximum developmental impacts of a pension to be felt as a result of people being able to plan their expenditure. Late or irregular payments can foster a reliance on informal credit, often at high interest rates which erode benefits and can create debt traps.

Many pension schemes pay cash to beneficiaries on a monthly basis. However, this is not always the case. Some pension schemes - in which the monthly grant is relatively low - pay less frequently. It may be possible to pay the pension every two or three months. This helps save on administrative costs. Payments that are less frequent than every three months are not advisable since beneficiaries are likely to spend long periods without access to cash. However, whatever the frequency of payment chosen, it is critical that payments are predictable.

There are two types of payment mechanism used in the delivery of pensions:

- 'Pull mechanisms' - Beneficiaries are pulled to the payment which is on a fixed date at a fixed location. One problem with this form of payment is that it can result in long journeys for people to access cash and long queues as everyone is accessing payments at the same time. It is also a costly way of transferring cash and, generally, payment is only made this way when there is no other option.

- 'Push mechanisms' - Cash is 'pushed' directly to recipients via an intermediary device such as a smartcard, bank account or mobile phone. Recipients can then choose when and where is best for them to access their cash payment. This payment device is more cost-effective as it is largely electronic rather than relying on significant staff resources. In addition, delivery would usually be through the private sector which reduces the pressure on Government capacity and also supports improved private sector infrastructure.

Using new technology to make payments could help bring about a technological revolution in the banking sector in Sri Lanka, bringing financial services much closer to rural communities. Once banks are interacting on a regular basis with pension beneficiaries, they could also begin to offer banking services to other community members.

The simplest and least costly "push" delivery method for Sri Lanka is to issue each pensioner with a debit card that can be centrally recharged each month and used to withdraw cash at any Automated Teller Machine (ATM) or bank with computer connections. The cost of this service is trivial, less than one per cent of the value of payments.

Unfortunately, two-thirds or more of pension beneficiaries are likely to live in rural areas without access to ATMs or modern banking facilities. One option is to deliver the benefits of these pensioners through post offices. The Ceylon Electricity Board pays Sri Lanka Post a $2 \%$ commission for receiving and processing electricity bills. A similar charge should suffice for delivery of pension benefits.

The other option could be to put out a call for tender for the delivery of cash payments and encourage banks to apply. International advice could be sought on 
A universal pension for Sri Lanka

how to extend the banking system to rural areas using low-cost innovative technology (e.g. through mobile phones). In the five years since the Kosovo universal pension started, the number of banks in the country has tripled (Gubbels et al. 2007). This demonstrates how, potentially, in Sri Lanka it may be possible to extend access to banks to many communities that do not currently have it. 


\section{Conclusion}

A universal pension is both affordable and feasible in Sri Lanka with no need for targeting. It is clear that the existing pension system in Sri Lanka is severely flawed. Even if existing pension schemes were improved, they would still not be able to provide a guaranteed minimum income for all older people, in particular those living in poverty. International experience indicates that a universal pension scheme is relatively simple to put in place and, once established, is very simple to administer. The impacts of such pensions on the lives of older people are significant.

Sri Lanka's population is ageing rapidly. Older people are likely to become a more powerful force politically in the next few years. It is essential that an effective pension system - based on the foundation pillar of a universal pension - is put in place as soon as possible. Fortunately, international experience demonstrates that a universal pension is very popular politically and so it is highly likely that a decision to move ahead will be received positively by the vast majority of citizens. 


\section{References}

Anonymous (2008). NSB pension plan successful. Financial Times, Colombo, 4 May 2008. http://sundaytimes.lk/080504/FinancialTimes/ft306.html Accessed 6 September 2008.

Ardington, E \& Lund, F. (1995). Pensions and development: The social security system as a complementary track to programs of reconstruction and development. Development Southern Africa Vol. 12, 557-77

Arenas de Mesa, Alberto and Carmelo Mesa-Lago (2006). "The structural pension reform in Chile", Oxford Review of Economic Policy 22:1 (Spring), pp. 149167.

Barrientos, A., and Lloyd-Sherlock, Peter (2002) Non-Contributory Pensions and Social Protection, 'Issues in Social Protection' Series, Social Protection Sector, ILO

Central Bank of Sri Lanka (2006). Employees' Provident Fund - Annual Report 2006, Colombo.

Central Bank of Sri Lanka (2008). Economic and Social Statistics of Sri Lanka 2008, Colombo, March.

Croome David and A. Nyanguru (2007) The Impact of the Old Age Pension on Hunger and Vulnerability in a Mountain Area of Lesotho, Report written for the Regional Evidence-Building Agenda (REBA) of the Regional Hunger and Vulnerability Programme (RHVP).

De Silva, W. Indralal (2007). A population of Sri Lanka for the new millennium, 20012101: trends and implications. Institute for Health Policy, Colombo, June.

Devereux, Stephen (2001) Social Pensions in Namibia and South Africa, IDS Discussion Paper 379, February 2001, Brighton: IDS

Dutrey, Alexander Peyre (2007). Successful targeting? Reporting efficiency and costs in targeted poverty alleviation programmes. UNRISD, Social Policy and Development Programme Paper No. 35, November.

Eriyagama, Vindya and Ravi P. Rannan-Eliya (2003). Assessment of the Farmers' and Fishermen's Pension and Social Security Benefit Scheme in Sri Lanka. Institute of Policy Studies, Colombo, August.

Fultz, E. \& Pieris, B (1999). Social security schemes in Southern Afirica: An overview and proposals for future development. Discussion Paper No. 11. Harare, Zimbabwe: ILO Southern Africa Multidisciplinary Advisory Team.

Gaminiratne, Nirosha (2004). Population Ageing, Elderly Welfare, and Extending Retirement Cover: The Case Study of Sri Lanka. ESAU Working Paper 3, Overseas Development Institute, London, April.

Gopalakrishnan, A. (2008). Anomaly in BoC, People's Bank pensions. Sunday Observer, Colombo, 17 February 2008. 
A universal pension for Sri Lanka

http://www.sundayobserver.lk/2008/02/17/main_Letters.asp Accessed 25 September 2008.

Grosh, Margaret E., Carlo Del Ninno, Emil Tesliuc and Azedine Ouerghi (2008). For Protection and Promotion: The Design and Implementation of Effective Safety Nets. World Bank, Washington, DC.

Gubbels, John, David Snelbecker and Lena Zezulin (2007) The Kosovo Pension Reform: Achievements and Lessons. Social Protection Discussion Paper No. 0707, April 2007. World Bank.

Heston, Alan, Robert Summers and Bettina Aten (2006). Penn World Table version 6.2. Center for International Comparisons of Production, Income and Prices at the University of Pennsylvania, September.

Holzmann, Robert, Richard Hinz and others (2005). Old-Age Income Support in the Twenty-first Century: an International Perspective on Pension Systems and Reform. World Bank, Washington, D.C.

Juurikkala, Oskari (2008). "Punishing the poor: a critique of means-tested retirement benefits", Economic Affairs 28:1 (March), pp. 11-16.

Kaniki (2007) Mauritius Case Study. Unpublished Manuscript from Economic Policy Research Institute, Cape Town

Kidd, Stephen and Edward Whitehouse (2008) Pensions and Old Age Poverty. Manuscript to be published by World Bank.

Kleven, Henrik Jacobsen and Wojciech Kopczuk (2008). Transfer program complexity and the take up of social benefits, NBER Working Paper No. 14301, September.

Lund, Francie (2002) Crowding in Care, Security and Micro-Enterprise Formation: Revisiting the Role of the State in Poverty Reduction and in Development. Journal of International Development Vol. 14, 1-14.

Ministry of Community Development and Social Services and GTZ (2005) First Monitoring Report: Pilot Cash Transfer Scheme, Kalomo District, Zambia.

Mauritius (2005). Government programme 2005-2010. Address by the President of the Republic.

http://www.gov.mu/portal/site/president/menuitem.d8599776370e1fdb9583d2f d0bb521ca/ Accessed 26 September 2008.

Mkandawire, Thandika (2005) Targeting and Universalism in Poverty Reduction. Social Policy and Development Programme Paper, Number 23, December 2005. United Nations Research Institute for Social Development.

Nyanguru, A.C. (2007). The economic and social impacts of the old age pension on the protection of the Basotho elderly and their households. National University of Lesotho, June. http://web.up.ac.za/UserFiles/A\%20Nyanguru\%20paper.pdf Accessed 23 September 2008.

Preston, David A. (2001). Retirement income in New Zealand: the historical context. Office of the Retirement Commissioner, Wellington, New Zealand. 
Rannan-Eliya, Ravi P. (2006). Sri Lanka's schemes for informal sector workers. Bangkok, November. http://www.ihp.lk/publications/pres_doc/pres061130.pdf Accessed 26 September 2008.

Rohter, L. (2006). Chile's candidates agree to agree on pension woes. New York Times, January 10.

Rowe, Nicholas and Frances Woolley (1999). "The benefits of universality", Policy Options (June), pp. 57-60.

Samson, Michael et al (2004) The Social and Economic Impact of South Africa's Social Security System. EPRI Research Paper Number 37

Samson Michael. (2006) Social Pensions and Poverty Reduction. Unpublished paper at Social Pensions Symposium at International Federation of Ageing $8^{\text {th }}$ Global Conference on Ageing.

Samson, Michael (2007) "Promoting economic growth" Ageways, Issue 70 (February).

Sri Lanka Department of Census and Statistics (2004). Announcement of the official poverty line, June.

http://www.statistics.gov.Ik/poverty/OfficialPovertyLineBuletin.pdf Accessed 28 September 2008.

Sri Lanka Department of Census and Statistics (2008). Price Bulletin, August. http://www.statistics.gov.lk/price/Bulletin/Price\%20Bulletin\%20of\%20August.p df Accessed 4 October 2008.

St. John, Susan and Larry Willmore (2001). "Two legs are better than three: New Zealand as a model for old age pensions", World Development 29:8 (August), pp. 1291-1305

Subramanian, A. and D. Roy (2001). Who can explain the Mauritian miracle: Meade, Romer, Sachs or Rodrik? IMF Working Paper WP/01/116, August.

Willmore, Larry (2003). Universal pensions in Mauritius: lessons for the rest of us, United Nations DESA Discussion Paper 32, April.

Willmore, Larry (2006). "Universal age pensions in developing countries: the example of Mauritius", International Social Security Review 59:4 (October), pp. 67-89.

Willmore, Larry (2007). "Universal pensions for developing countries", World Development 35:1 (January), pp. 24-51.

World Bank (1994). Averting the old age crisis: policies to protect the old and promote growth. Oxford University Press, New York.

World Bank (2008). Sri Lanka: addressing the needs of an aging population. Human Development Unit, South Asia Region, June 12. 


\section{Annex A: International experience with universal pensions}

Few countries offer basic pensions to everyone. Willmore (2007) was able to identify universal pension schemes in only eight nations, plus Kosovo and Mexico City (table 1.) The Netherlands (from age 65) and Norway (from age 70) offer tax-financed, basic pensions that are universal except for the requirement of many years of residence for a full pension: 50 years between the ages of 15 and 64 in the Netherlands, 40 years between the ages of 16 and 66 in Norway. A few countries notably South Africa, Australia, Brazil, Lesotho (from 2004) and Chile (from 2008) exclude only a few, providing benefits to between $60 \%$ and $90 \%$ or more of those who meet age requirements. More common are tightly targeted social pensions that governments offer to around $5 \%$ to $25 \%$ of residents who qualify by age.

New Zealand was one of the first countries in the world to introduce an age pension, in 1898. From the start, the pension was tax-funded, flat-rate and non-contributory. In accordance with Victorian standards, the benefit was paid to those older than 65 years, of non-Asiatic origin, who were able to pass a means test and a test of "good" character. Following the upheaval of the Great Depression, a universal benefit was introduced in 1940 for those 65 years of age and older (see St. John \& Willmore, 2001; Preston, 2001).

New Zealand has never demanded that workers contribute to a provident fund, nor to any retirement saving scheme. Perhaps for this reason, the flat benefit is generous, $46 \%$ of per capita GDP from age 65 and indexed to wages. A married person living with his or her age-qualified spouse receives a benefit that is nearly $25 \%$ smaller. The penalty does not apply to other pensioners living together, such as two older sisters, or an older man with his older sister. The rule defies logic, introduces complexity, and is probably not a good one for Sri Lanka to imitate. All pensions are taxable as income, so the fiscal cost of the scheme is $4.3 \%$ of GDP gross (before tax) but only $3.6 \%$ net (considering income taxes collected on the benefits).

Mauritius introduced its first age pension in 1950, when it was a colony of Britain and highly dependent on production and export of sugar. Initially, the benefit was given to those over the age of 65 who passed an income test. In 1953 the qualifying age was reduced to 60 years for women and in 1965 for everyone. The income test applied only to individual income or, if an applicant was married, to the combined income of husband and wife. The income of the rest of the household was never considered. This test reduced the number of beneficiaries by $20 \%$ or $25 \%$ compared to a universal programme, similar to the means test in effect in South Africa today. Some political leaders wished to reduce the number of pensioners by imposing a harsher test, one that took into account also the income of adult children. These proposals were defeated in the colony's Legislative Council. (For details, see Willmore, 2003 and 2006.)

The income test in Mauritius was widely perceived as unfair, for two reasons. First, it rewarded cheaters and penalised honest citizens. Those who reported earnings saw their benefits reduced by the full amount, so they quickly learned to hide their true income. Second, many in Mauritius were convinced that all residents, and certainly those with relatively high income and consumption, earned the right to a pension in old age by paying taxes. 
Another complaint was that the test empowered bureaucrats, and corruption often accompanied this power. A government minister explained in April of 1958 that this was a key reason why the government decided to table legislation to transform the pension into a universal benefit:

"[We] know that if an unfortunate person applies for old age pension and does not have any support, it would take months ... [to] obtain the old age pension. I can very well understand why certain elements in the country are against the doing away of the means test. Once this is got rid of, every person who is entitled to receive old age pension would be able to apply for it and, as a matter of law, as a matter of right, will be entitled to it. It will not be a question of whether one Member of the House or some of his friends happen to be persona grata with certain officers... This is one way in which up to now political power has been obtained in certain quarters in this country. This is a fact... and this is one of the things which this Government has decided to stop." (Mr. Rault, 1 April 1958, cited in Willmore, 2003)

When an applicant can qualify for a pension simply by submitting proof of age, the government official has little power. Complex rules requiring certification of an applicant's economic and social status provide opportunities for corruption and for abusive invasion of privacy.

In 1983 Mauritius increased the basic pension by $15 \%$ for those aged $75-89$ and by $72 \%$ for those aged 90 and over. This unique policy continues to be popular, and some birthdays - particularly the 90th - are cause for great celebration. The age categories have changed several times over the years, and the age gap in pension benefits has grown. Pensioners $100+$ years old now receive benefits equivalent to $68 \%$ of per capita GDP, those aged $90-99$ receive $60 \%$, while benefits for the remainder, aged $60-89$ years, are equal only to $16 \%$ of per capita GDP. Those aged 90 years and older account for approximately $2 \%$ of pensioners, so the fiscal cost of this generosity to the "oldest old" is low. The gross transfer to older people amounts to $1.7 \%$ of GDP. Pensions in Mauritius are taxable as income, as they are in New Zealand, but there is no estimate of taxes paid on pension income, so no estimate of net transfers.

Since 1976 Mauritius has provided four additional types of pensions on a universal basis to residents who are too young to qualify for an age pension. These are: (1) a basic widow's pension, payable to widows younger than 60 unless they remarry, (2) a basic invalid's pension for the severely disabled, (3) a child's allowance for the first three children of a widow, payable to the age of 15 (20 if in full-time study), and (4) a basic orphan's allowance paid to a full orphan up to the age of 15 (20 if in full-time study). The widow's and invalid's pensions are roughly the amount of an age pension, and they cease at age 60 when the beneficiaries become eligible for a standard pension. The orphan's allowance is roughly half the size of the age pension; each child's allowance is approximately a third of widow's pension. No income tests or assets tests are demanded of applicants. Mauritius seems to be unique in providing such pensions without any test of means, and they are very important for the income security of families who have the misfortune to experience the early death or disability of the principal breadwinner. The benefits of these pensions are in addition to the "benefits transferred" reported in Table 1. 


\title{
Annex B: The possibility of rule-based targeting in Sri Lanka
}

\begin{abstract}
Light and simple targeting can reduce the complexity of means tests, along with corresponding administrative and governance problems. In Sri Lanka, for example, it is feasible to deny social pensions to anyone who has worked in the public sector or in the formal private sector. This could be accomplished with a rule that an older person can receive a social pension only if he or she is does not receive a public sector pension and has never filed personal income tax or contributed to a provident fund. Such a rule would deny social pensions to more than a third of the labour force. It is easy to extend this prohibition of social pensions to dependent spouses as well, since their names are a matter of public record, so the fiscal cost of the social pension could easily be reduced by a third compared to the fiscal cost of a universal pension.
\end{abstract}

Light, rule-based targeting is an improvement over audits of income and assets, but it has three disadvantages compared with universal pensions:

- Targeting is crude. It is nearly certain that a portion of those excluded from pensions will live in greater poverty than many who are included. An older person may have worked only a few months or years in the formal sector of the economy. Or, even with a full career in formal employment, they might outlive their savings. Few workers in the private sector receive pensions upon retirement. Public sector workers receive what is initially a generous pension, but it is not indexed for price inflation. If ad hoc adjustments fail to keep pace with increases in the cost of living, public sector workers and their widows can suffer poverty despite access to a pension.

- Targeting is a form of taxation, so the tax saving is an illusion. (Rowe \& Woolley, 1999; Juurikkala, 2008). This point is subtle, and poorly understood even by trained economists, but it is important. Using the fiscal cost calculations for 2007 reported in table 2, suppose that we select 60 years as the qualifying age. Approximately 2.1 million people would be eligible for a universal pension, and the fiscal cost would be about US\$ 580 million. Suppose we reduce the fiscal cost to US $\$ 385$ million by eliminating 700,000 old people from the pension list with a public pension/income tax test. In reducing costs, we also reduce benefits. Each person excluded from the social pension loses access to US $\$ 21$ a month in benefits. This is a tax on old people. Is this a fair or just way to finance a social pension? The net savings - even assuming costless administration of the light targeting - is trivial. The only savings are costs of administration, equal (we assume) to US\$1.05 a month for each old person removed from the social pension. With targeting, the social cost of age pensions remains nearly the same, but their burden falls heavily on older people.

- Targeting distorts choices by encouraging workers to remain in the informal sector where labour is not taxed, since targeting is a form of taxation. Working in the formal sector - even for a brief period - comes at a high price, namely exclusion from the benefit of a social pension. All taxes distort choices, but low taxes collected from the entire population are less distorting than high taxes collected from a small group of people. Targeting is not only unfair, it is inefficient. 


\section{Annex C: Pension-testing a non-contributory pension}

An apparently simple and effective way of saving taxpayers' money is to opt for pension-testing by providing a guaranteed minimum pension instead of a universal pension. This is a means test, but one where the test is not assets or income in general, but only income from a pension. It is also an example of rules-based targeting. Like all targeting, it is equivalent to a tax, in this case a tax on pension income.

Lesotho, an enclave of South Africa, in November 2004 began to distribute age pensions to its citizens aged 70 years and older, who account for $3.3 \%$ of the total population of 2.3 million. The age benefit was initially set at 150 maloti (US\$24) a month, 2 maloti above the national poverty line and equivalent to $46 \%$ of Lesotho's per capita GDP. This was increased in 2007 to 200 maloti (US $\$ 28$ ), $51 \%$ of that year's per capita GDP. The pension scheme requires approximately $1.4 \%$ of GDP to provide benefits to 69,000 of the 74,000 age-qualified persons. No one is allowed to receive more than one pension from the government, so those receiving an occupational pension had to choose between that pension and the new age pension. Some 5,000 of older people - largely former civil servants who had occupied relatively well-paid positions - elected to keep their occupational pensions. An unknown number lost their small occupational pension when they switched to the new, higher age pension (see Nyanguru 2007).

Perhaps because of the way the policy was framed - one pension per person - it had the appearance of fairness and appears to have been well received. Lesotho's age pension nonetheless is a guaranteed minimum pension, not a universal pension. Precisely the same policy could have been carried out in a different manner, in a way that highlights the true distribution of the burden of costs. All 74,000 older people could have been given age pensions, and occupational pensions could have been reduced by $100 \%$ of the social pension or the full amount of the occupational pension, whichever was smaller. This is a tax on pension income at the punitive rate of $100 \%$ for small pensions. It is a tax that falls heavily on retired schoolteachers and other low-paid public servants.

In Sri Lanka, as in Lesotho, few older people other than retired public servants have access to income from a pension. Would these pensioners accept such a great sacrifice to help make age pensions more affordable for the rest of the population? Perhaps. Or perhaps not. Workers presumably accept lower pay for public sector jobs than they would for comparable private sector employment because of the income security that a pension provides. Those who choose employment at higher pay in the private sector have opportunities to save for retirement, both through the provident fund and privately, so why should former public servants shoulder a disproportionate burden? These are questions policy-makers will have to ponder.

There are at least two more examples of functioning minimum pensions: Sweden and Finland. Both countries offer non-contributory pensions to nationals from age 65 , but require 40 years' residence (from age 25 in Sweden, from age 15 in Finland) for a full pension. Both recover or 'claw back' this benefit from other pension income. Finland claws it back at the rate of $50 \%$ and Sweden at the rate of $100 \%$. A $50 \%$ rate allows a pensioner to retain at least part of the basic pension so long as other pension income is less than twice the basic pension; with a $100 \%$ rate, none of the basic 
pension is retained once other pension income reaches the level of the basic pension.

Chile in July of 2008 implemented a new non-contributory Solidarity Pension System that guarantees a minimum pension to almost everyone. The minimum was initially set at 60,000 pesos (US\$111) and will increase to 75,000 pesos (US\$135) in July 2009. These amounts respectively are about $16 \%$ of the country's 2008 per capita GDP and $18 \%$ of the country's expected 2009 per capita GDP. The minimum pension does not apply to everyone because of a means test that is supposed to exclude households in the upper $40 \%$ of the income distribution. It remains to be seen whether this targeting will be effective. There is no longer any limit on the number of non-contributory pensions, so mis-targeting of pensions to those in the upper reaches of the income distribution will affect only the national budget, not the allocation of pensions to lower-income citizens. Claw-back of the minimum pension from other pension income will initially be at the rate of $100 \%$, as in Lesotho and in Sweden. It is programmed to fall to $75 \%$ in $2010,50 \%$ in 2011 and $37.5 \%$ in 2012.

Even a $37.5 \%$ claw-back rate is a powerful incentive to withdraw from participation in contributory pensions, especially in the case of lower-income workers or secondary workers who have little attachment to the labour force. Finland can claw back its minimum pension at a rate of $50 \%$ and Sweden at a rate of $100 \%$ because those countries have only a trivial amount of informal labour. Their governments are able to force nearly all workers to pay taxes and pension contributions on their earnings.

This is not the case for Chile, which has a large informal sector. And it is not the case either for Sri Lanka, which has an even larger informal sector.

As the rate of claw-back falls, a guaranteed minimum pension comes to resemble a universal pension. In fact, a universal pension can be described as a minimum pension with no claw-back and no means test.

Current conditions in Sri Lanka do not look promising for pension-testing a noncontributory social pension. Few older people other than retired public servants have pensions, so the gains from taxing these pensions will be small, and the disincentives to participate in retirement pension schemes will be great. To generate substantial fiscal savings, a guaranteed minimum pension would have to be combined with wide participation in contributory pension schemes that offer benefits more generous than the guaranteed minimum. 


\section{Annex D: Calculations of fiscal cost}

Table D1. Projections of per capita GDP and GDP, 2007-2041 (constant 2007 rupees)

\begin{tabular}{|l|r|r|r|r|r|r|r|r|}
\hline Year & $\mathbf{2 0 0 7}$ & $\mathbf{2 0 1 1}$ & $\mathbf{2 0 1 6}$ & $\mathbf{2 0 2 1}$ & $\mathbf{2 0 2 6}$ & $\mathbf{2 0 3 1}$ & $\mathbf{2 0 3 6}$ & $\mathbf{2 0 4 1}$ \\
\hline $\begin{array}{l}\text { per capita GDP } \\
\text { (thousand LKR) }\end{array}$ & & & & & & & & \\
\hline past trend & 180 & 207 & 247 & 295 & 352 & 421 & 502 & 599 \\
\hline slow growth & 180 & 193 & 211 & 231 & 253 & 276 & 302 & 330 \\
\hline & & & & & & & & \\
\hline GDP (million LKR) & & & & & & & & \\
\hline past trend & 3578386 & 4261753 & 5241422 & 6371748 & 7683165 & 9202454 & 10961753 & 13004993 \\
\hline slow growth & 3578386 & 3973199 & 4476528 & 4985296 & 5506968 & 6042494 & 6593753 & 7166430 \\
\hline
\end{tabular}

Memorandum: annual growth of

$$
\text { GDP per capita GDP }
$$

$$
\begin{aligned}
& \text { 1980-2007 } \\
& \text { 2007-2041 (past trend) } \\
& \text { 2007-2041 (slow growth) }
\end{aligned}
$$

$\begin{array}{ll}3.6 \% & 4.8 \% \\ 3.6 \% & 3.7 \% \\ 1.8 \% & 1.9 \%\end{array}$

Note: per capita GDP was projected with an annual growth of $3.6 \%$ (past trend) and $1.8 \%$ (slow growth). GDP is simply the per capita figure multiplied by projected population.

Source: Calculations based on GDP data from IMF World Economic Outlook Database (April 2008) and the standard population projection of De Silva (2007). 
Table D2. Population ageing in Sri Lanka, 2006-2041

\begin{tabular}{|l|r|r|r|r|r|r|r|r|r|}
\hline Year & $\mathbf{2 0 0 6}$ & $\mathbf{2 0 0 7}$ & $\mathbf{2 0 1 1}$ & $\mathbf{2 0 1 6}$ & $\mathbf{2 0 2 1}$ & $\mathbf{2 0 2 6}$ & $\mathbf{2 0 3 1}$ & $\mathbf{2 0 3 6}$ & $\mathbf{2 0 4 1}$ \\
\hline Total population (thousands) & 19719.6 & 19884.5 & 20557.8 & 21185.5 & 21579.9 & 21803.8 & 21882.5 & 21841.1 & 21712.3 \\
\hline Population 75+ (thousands) & 491.5 & 508.9 & 584.8 & 673.3 & 823.7 & 1064.7 & 1281.3 & 1491.8 & 1680.1 \\
\hline Population 70+ (thousands) & 876.9 & 902.7 & 1013.8 & 1223.0 & 1550.8 & 1869.2 & 2189.6 & 2469.0 & 2686.5 \\
\hline Population 65+ (thousands) & 1375.8 & 1426.8 & 1650.7 & 2061.2 & 2474.0 & 2907.3 & 3301.5 & 3609.0 & 3871.8 \\
\hline Population 60+ (thousands) & 2075.7 & 2166.4 & 2570.4 & 3070.2 & 3605.1 & 4115.0 & 4536.1 & 4888.8 & 5386.7 \\
\hline Population 75+ (\%) & 2.5 & 2.6 & 2.8 & 3.2 & 3.8 & 4.9 & 5.9 & 6.8 & 7.7 \\
\hline Population 70+ (\%) & 4.4 & 4.5 & 5.1 & 5.8 & 7.2 & 8.6 & 10.0 & 11.3 & 12.4 \\
\hline Population 65+ (\%) & 7.0 & 7.2 & 8.0 & 9.7 & 11.5 & 13.3 & 15.1 & 16.5 & 17.8 \\
\hline Population 60+ (\%) & 10.5 & 10.9 & 12.5 & 14.5 & 16.7 & 18.9 & 20.7 & 22.4 & 24.8 \\
\hline
\end{tabular}

Note: The 2007 figures were estimated by interpolation using logarithms, equivalent to an assumption of constant growth from 2006 to 2011.

Source: De Silva (2007), standard projection, appendix tables 1-9.

Table D3. Projected cash transfers of a universal pension in Sri Lanka, 2007-2041, constant 2007 rupees

\begin{tabular}{|l|r|r|r|r|r|r|r|r|}
\hline Year & $\mathbf{2 0 0 7}$ & $\mathbf{2 0 1 1}$ & $\mathbf{2 0 1 6}$ & $\mathbf{2 0 2 1}$ & $\mathbf{2 0 2 6}$ & $\mathbf{2 0 3 1}$ & $\mathbf{2 0 3 6}$ & $\mathbf{2 0 4 1}$ \\
\hline Monthly benefit (LKR) & 2321 & 2321 & 2321 & 2321 & 2321 & 2321 & 2321 & 2321 \\
\hline Total transfer (million LKR) - 75+ & 14210 & 16288 & 18753 & 22942 & 29654 & 35687 & 41550 & 46794 \\
\hline Total transfer (million LKR) - 70+ & 25187 & 28236 & 34063 & 43193 & 52061 & 60985 & 68767 & 74824 \\
\hline Total transfer (million LKR) - 65+ & 39851 & 45975 & 57409 & 68906 & 80974 & 91953 & 100518 & 107837 \\
\hline Total transfer (million LKR) - 60+ & 60567 & 71591 & 85511 & 100409 & 114611 & 126339 & 136163 & 150030 \\
\hline
\end{tabular}

Source: Calculations from population projections of table D2. 
Table D4. Projected fiscal costs of a universal pension in Sri Lanka, 2007-2041, percentage of GDP

\begin{tabular}{|c|c|c|c|c|c|c|c|c|}
\hline Year & 2007 & 2011 & 2016 & 2021 & 2026 & 2031 & 2036 & 2041 \\
\hline \multicolumn{9}{|l|}{ Trend growth - $3.6 \%$} \\
\hline $60+$ & 1.80 & 1.78 & 1.73 & 1.67 & 1.58 & 1.46 & 1.32 & 1.22 \\
\hline $65+$ & 1.19 & 1.15 & 1.17 & 1.15 & 1.12 & 1.06 & 0.98 & 0.88 \\
\hline $70+$ & 0.75 & 0.71 & 0.70 & 0.73 & 0.73 & 0.71 & 0.67 & 0.62 \\
\hline $75+$ & 0.43 & 0.41 & 0.39 & 0.39 & 0.42 & 0.42 & 0.41 & 0.39 \\
\hline \multicolumn{9}{|l|}{ Slow growth $-1.8 \%$} \\
\hline $60+$ & 1.80 & 1.91 & 2.03 & 2.14 & 2.21 & 2.22 & 2.19 & 2.22 \\
\hline $65+$ & 1.19 & 1.23 & 1.37 & 1.47 & 1.57 & 1.62 & 1.62 & 1.60 \\
\hline $70+$ & 0.75 & 0.76 & 0.81 & 0.93 & 1.01 & 1.08 & 1.12 & 1.12 \\
\hline $75+$ & 0.43 & 0.44 & 0.45 & 0.50 & 0.58 & 0.64 & 0.68 & 0.70 \\
\hline
\end{tabular}

Note: Includes basic age pensions, death benefits, and $5 \%$ administrative costs.

Source: Calculations from data of table 2 and annex tables D1 and D2. 
